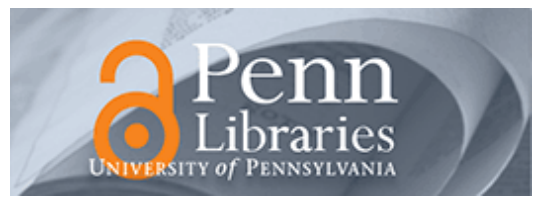

University of Pennsylvania

ScholarlyCommons

Finance Papers

Wharton Faculty Research

6-1988

\title{
The Implications of Insurance for the Efficacy of Fiscal Policy
}

Andrew B. Abel

University of Pennsylvania

Follow this and additional works at: https://repository.upenn.edu/fnce_papers

Part of the Finance Commons, Finance and Financial Management Commons, and the Taxation Commons

Recommended Citation

Abel, A. B. (1988). The Implications of Insurance for the Efficacy of Fiscal Policy. The Journal of Risk and Insurance, 55 (2), 339-378. http://dx.doi.org/10.2307/253335

This paper is posted at ScholarlyCommons. https://repository.upenn.edu/fnce_papers/170

For more information, please contact repository@pobox.upenn.edu. 


\title{
The Implications of Insurance for the Efficacy of Fiscal Policy
}

\author{
Abstract \\ Various tax policies provide consumers with forms of insurance. Social security has the payoff \\ characteristics of an annuity. The income tax provides consumers with a degree of Income insurance \\ because the government shares part of the individual's income risk. Redistributive taxes can be used to \\ spread aggregate income risks across different generations The effects of these and other tax policies \\ are shown to depend crucially on the nature of existing private insurance arrangements. \\ Disciplines \\ Economics | Finance | Finance and Financial Management | Taxation
}


NBER WORKING PAPER SERIES

THE IMPLICATIONS OF INSURANCE FOR

THE EFFICACY OF FISCAL POLICY

Andrew B. Abel

Working Paper No. 2517

NATIONAL BUREAU OF ECONOMIC RESEARCH

1050 Massachusetts Avenue

Cambridge, MA 02138

February 1988

This paper was prepared for presentation to the American Risk and Insurance Association in Montreal, August 16, 1987. I thank J. David Cummins for discussion and Stephen Zeldes and Stanley Fischer for comments on an earlier draft. Financial support from the National Science Foundation, the Sloan Foundation, and the Amoco Foundation Term: Professorship in Finance is gratefully acknowledged. The research reported here is part of the NBER's research program in Economic Fluctuations. Any opinions expressed are those of the author and not those of the National Bureau of Economic Research. 
NBER Working Paper \#2517

February 1988

\section{The Implications of Insurance for the Efficacy of Fiscal Policy}

\section{ABSTRACT}

Various tax policies provide consumers with forms of insurance.

Social security has the payoff characteristics of an annuity. The income tax provides consumers with a degree of income insurance because the government shares part of the individual's income risk:

Redistributive taxes can be used to spread aggregate income risks across different generations. The effects of these and other tax policies are shown to depend cruclaliy on the nature of existing privare insurance arrangements.

Andrew Abel

Department of Finance

The Wharton School

Steinberg Hall, Room 2319

University of Pennsylvania

Philadelphia, PA 19104 


\section{Introduction}

What does insurance have to do with the macroeconomic effects of Eiscal policy? To an economist schooled in the traditional Keynesian multiplier analysis, the answer would be a resounding "nothing!" In the simplest Keynesian paradiga, the effects of fiscal policy are analyzed using the multiplier, which is based on a simple marginal propensity co consure. The role of uncertainty--not to mention insurance-m is not at all apparent in this analysis. However, nacroeconomics and the analysis of fiscal policy have progressed well beyond this simple framework.

Consumption behavior continues to be stressed in analyzing the effects of fiscal policy, but the mechanisus that are currenty emphasized are quite different from those in the early Keynesian framework.

Most recent theoretical research on the effects of fiscal policy. proceeds by examining the effects of fiscal policy on the consumption and portfolio decisions of individual consumers. The racroeconomic effects of fiscal policy are then determined by aggregating the behavior of individual consumers. If all consumers are idencical, then, of course. aggregation is particularly simple. Alternatively, if, as in much of the research presented below, there is heterogeneity among consumers, then the aggregation of individual behavior must explicitly take account of general equilibrium considerations and market-clearing relations.

The preferred frameworks for analyzing individual consumption behavior are the life-cycle model of Modigliani and Brumberg [22] and the permanent income model of Friedman [12]. Each of these approaches is based on explicit utility maximization by an individual consumer subject to the constraints that face that consumer. The important insight shared by these theories is that consumers form their consumption decisions on 
the basis of their lifetime income rather than simply their current income as in the Keynesian consumption function. Optimal consumption behavior requires consumers to forecast their future after-tax incomes. Therefore, in responding to a tax change, for example, consumers must forecast the future course of taxes as well as the current tax. Because future incomes and taxes are not perfectly predictable, there is a demand by rik-averse consumers for insurance. The savings and consumption decisions of individual consuners will be greatly affected by whether insurance of various types $f_{a}$ avaluble and, if so, at what price. In particular, the responses of individual consumers to various changes in taxes depend on the nature of available insurance arrangements.

In discussing the importance of insurance arrangements, a broad definition of insurance will be used. For the purposes of this paper, insurance 1$] 1$ be defined as any contingent arrangement that allows individual consumers to mighate random fluctuatons in marginal utility. This defintion is deliberately general in order to convey the view that insights about insurance can be applied to questions that at first glance do not appear to have anything to do wth insurance.

The majority of this paper is devoted to situations in which individuals face idiosyncratic risks. More precisely, much of the analysis examines situations in which a group of individuals all face the same ex ante probability distribution for a random variable; but, ex post, different members of the group obtain different realizations of the random veriable. If each individual's realization of this random variable were publicly observable, there would evidently be scope for private insurance markets to pool these idiosyncratic risks. By contrast, the last part of this paper will ignore idiosyncratic risks and 
will focus instead on aggregate risks, in which all members of a cohort experience the same realization of the random variable. In this situation, the scope for private insurance is less evident, but a fiscal authority could provide insurance.

The particular risks analyzed in this paper are of three sorts. The first risk, which is discussed in section II, is associated with the fact that individuals do not know in advance exactly when they will die. After analyzing the implications of this individual longevity risk for individual saving and the distribution of wealth, this framework is used to analyze the effects of social security in the presence of alternative private insurance arrangements. The second risk, discussed in section III, is associated with the unpredictability of future income, and it gives rise to precautionary saving. An income tax provides a form of insurance against fluctuations in income and thus mitigates the need for precautionary saving. This interaction of the insurance aspects of the income tax and saving behavior has important implications for the effects of fiscal policy. The third risk, which is analyzed in section IV, is a cohort-wide income risk that cannot be shared in private insurance arrangements. However, a fiscal system of taxes and transfers can be established to share this risk optimally across generations. After presenting the features of an optimal system, the viability of such a system is discussed.

\section{Longevity Risk}

Before analyzing the saving behavior of consumers in the presence of longevity risk, it is useful to summarize briefly the implications of the life-cycle model under the assumption that each consumer knows in 
advance how long he or she will live. The lifencycle model has two fundamental components. First, each individual cares about lifetime utility and, consequently, attempts to have a smooth profile of consumption over his or her lifetime. Second, there is a typical Iffecycle pattern of income in which individuals earn labor income during early and middle adulthood and are retired in late adulthood. In order to gckieve the sane level of consumption during retirement as during working years, it is necessary for individuals to save some of their labot income and accumbate weelth curing their working years. Then this weal th is gradually decumulated to provide for consumption during retirement.

In a particularly restrictive form of the life-cycle model, consumers are assumed not to have bequest motives. In this formulation then, it is optimal for a consmer to end life with precisely zero wealth. However, chis implication is simply not borne out by the data. While the implication ther consumers die holding zero wealth is perhaps too strong to be expected to hold exactly, many studies have indicated that consurers cecurulate wealth far too slowly, ot not at all. Does this failure of elderly consumers to decumulate their wealth indicate the importance of a bequest motive, does it indicate an imperfection in life and/or health insurance markets ${ }^{2}$, or does it indicate some more basic fay in the model? Although this question to still watting for a definitive answer, recent research, which has focussed on the role of insurance narkets and bequest motives, has produced a rich array of

1 See, for example, kotikoff and summers [21].

2 Davies [8] calibrated a theoretical model to actual mortality probabilities and concluded that the uncertainty about one's date of death could potentially explain the failure of elderly consumers to dissave. 
insights.

A. Absence of Private Annuities

To begin the study of saving and bequests under uncertain longevity, it is convenient to start with as simple a model as possible. This model is taken from Abel [1]. A similar model of individual behavior, which does not include a capital stock, is analyzed in Eckstein, Eichenbaum and Peled (10).

Suppose that each consumer can live for at most two periods. For the moment, assume that a consumer does not have a bequest motive and cannot buy life insurance or annuities. In the first period, the consumer receives an inheritance, $I$, and inelastically supplies one unit of labor thereby earning labor income $y$. Also in the first period, the consumer pays a tax $T$ and consumes an amount $c$. Therefore, the consumer's total wealth at the end of the first period of life, which is denoted by $W$, is

$$
W=T+Y-T-C
$$

Suppose that this wealth is held in the form of riskless capital and let $R$ denote the gross rate of return on wealth between the first and second periad. Thus, at the beginning of the second potential period of life, the consumer's wealth, including accrued interest, is $\mathrm{R}$. At the beginning of the second potential period of life, the consumer gives birth to $G$ heirs. After the $G$ heirs are born, the uncertainty about the consumer's longevicy is resolved. With probability $p$, the consumer dies at the beginning of the second period and the consumer's estate is divided equally among the $G$ heirs; thus each heir receives $R \mathrm{~W} / G$, Alternatively, with probability $1-p$, the consumer survives Each surviving consumer receives a social security benefit $s$. Knowing that 
this is the last period of his or her life, the consumer consumes his resources. Letting $x$ denote the consumption in the second pe Iife, it follons that

$$
x=R H+S=R[I+Y-T-C]+S
$$

Equation (2) is the consumer's iffetime budget constraint. next step is to specify the consumer's utility function. It is converiert to use the following special case of the rati. [26] w function

$$
\mathrm{U}=\ln c+(I-p) D \ln x
$$

where $0<D<1$ is a discount factor representing the pure rate preference. The utility of old age consumption is discounted bo because of time preference and because of uncertainty. The weigh is the probability of survival. ${ }^{3}$

To derive the optimal consumption in the first period, subs the budget constraint (2) into the utility function (3) so that of expected lifetime itility depends only on consumption when yot Differentiathg this expression with respect to $c$ and setting the derivative equal to zero yjelds the optimal level of consumption

$$
c=2[I+Y-T+S / R]
$$

where $a=1 /[1+(1-p) D)$. The coefficient $a$, which is between $z e r$ one, is the ranginal propensity to consure out of lifetime resou Note that, in calculating the present of value of lifecime resou social security benefit 5 is discounted by the riskless rate of

3 The utility function in (3) can be intexpreted as the expecte value of lifetime utility. Under this interpretation, it is imp assumed in (3) thet if the consumer dies at the begining of the period, then second-period utility is equal to zero. More gener could write (3) as $U=\ln c+(1-p) D$ In $x+p D$ where $\phi$ is th of second-period utility if the consumer dies young. Far the pu deriving the optimal behavior of the consumer, the value of $\phi$ is irrelevart.

distri

inheri

because

Substi

consump

Eype 0

corsump

inheri

consum

consum

Ir

weal th

by the

in (8)

type $j$

inheri

genera

itheri

was a 
received by a type $j$ consumer is

$$
I(j)=R W^{(j-1)} / G
$$

Equation (10) relates the inheritance of a type $j$ consumer to the wealth of a type $j-1$ consumer... Using this relation to substitute for the inheritance in (9) yields

$$
W^{(j)}-W^{(0)}+(1-a) R W^{(j-1)} / G
$$

* Equation (11) can be used to solve for the wealth of all consumers: Technically; it is a first-order I inear constant coefficient difference equation with the boundary condition given by (7). This equation can be easily solved. It can be shown that the wealth of a young type $j$ consumer, $w(j)$, increases monotonically in $j$ and, if $(1-a) R / G<1$, it approaches a finite limit as i approaches infinity. Rather than present the complete solution here, it is convenient to focus on the average value of $w^{(j)}$ in the steady state, which is denoted as $W^{*}$. It can be showr that

$$
N=-(0) /[1-(1-a) p R / G]
$$

The variable $W^{*}$ is an interesting macroeconomic quantity; in particular, it is the per capita value of the private capital stock. 5 To see that $W^{*}$ is the per capita stock of private capital, recall that surviving old consumers consume all of their resources. Thus, all private saving in the economy is done by young consumers. Since capital is the only asset in this economy, the saving of young consumers, which averages $W^{\star}$ per capita, is equal to the private capital stock.

This simple model endogenously generates a cross-sectional distribution of wealth. The mechanism generating the cross-sectional

4 See Abel [1] for a complete solution.

5. Strictly speaking, $W^{*}$ is equal to the total private capital stock of the economy divided by the number of young consumers, rather than divided by the total number of consumers. 
variation is that a fraction $p$ of each cohort of consuners dies young and thus leaves accidental bequeses to their heirs. In this model, all of the cross-sectional variation in wealth results from cross-sectional variation in bequests. An additional feature of this model is thet it predicts a potentially substantial ratio of bequests to total private wealth. Indeed, since a fraction $p$ of each type of consumer dies young, the ratio of bequests to total private wealth is equal to $p$.

Fully Funded Social Security: Although the model presented above is quite simple, it provides some important insights into the effects of a social insurance program. In particular, this nodel can be used to examine the effects on consumption, capital accumilation and the distribution of wealth of either a fully funded or a pay-as-you-go social security system.

First, consider the effects of a fully funded social security system. In such a system, the government collects a tax $T$ from each young consumer and invests the proceeds in capital. In the next period, the social security fund is worth RT and is distributed evenly to the surviving nembers of the cohort of elderly consuners. Thus, each surviving consumer recelves a social security payment s such that

$$
\mathrm{RT}=(1-\mathrm{p}) \mathrm{S}
$$

The effects of the introduction of social security can be evaluated by corparing the equilibrium values of variables under the social security system with the values that these variables would attain in the absence of social security (with $T=S-0$ ). The consumption of type 0 consumers can be calculated by substituring the relation between the social security parameters $S$ and $T$ in (13) into (6) to obtain

$$
c^{(0)}=a[Y+p T /(I-p)]
$$


Inspection of (14) reveals that the introduction of fully funded social security increases the consumption of young type 0 consumers by apT/(1-p). This increase in consumption reflects the intrarcohort risk pooling of the social security system. Each consumer contributes $\mathrm{T}$ to the social security system, but a fraction $p$ of each cohort dies young and thereby surrenders its clain to social securicy benefits to the remaining fraction $1-p$ of the cohort. Thus, risk pooling increases the present value of lifetime resources of each survivor by $\mathrm{pT} /(1-\mathrm{p})$. Multiplying this increase in lifetime resources by the marginal propensity to consume, $a$, yields the increase in consumption of young type 0 consumers.

The wealth hela by young type 0 consuners can be calculated by substituting the relation between the social security parameters $S$ and $T$ from (13) into equation (7) to obtain

$$
W^{(0)}-(1-a) Y-T-a p T /(1-p)
$$

The introduction of fully funded social security reduces the wealth held by young type 0 consumers, and this reduction in wealth is decomposed into two parts in (15). First, even if a young type 0 consumer maintained consumption unchanged with the introduction of social security, the consumer's wealth would decine by the amount of the social security tax, because first-period disposable income is reduced by $T$. Furthermore, as explained above, a young type 0 consumer increases consumption by apT/(1-p), which reduces saving by an additional apT/(1p).

Because the saving of young type 0 consumers is reduced by the introduction of fully funded social security, those type 0 consumers who die young leave smaller bequests in the presence of social security than 
in its absence. Therefore, the introduction of social security reduces the inheritances received by type 1 consumezs. These consumers in turn leave smaller bequests in the presence of social security than in its absence. Indeed, in the new steady state the accidental bequest left by each type $j$ consumer is reduced by the introduction of social security. Therefore, the introduction of social security reduces the inheritances received by all consumers (except for type 0 consumers who receive no inheritance in either case). gecause the only source of cross-sectional. variation is the intra-cohort variaton in inheritances, it follows that Fully funded social security harrows the steady state distributions of consumption and wealth. 6 In addition to reducing the intra-cohort variation in wealth, the introduction of fully funded social security affects the average level of wealth in the economy and the size of the national capital stock. The national capital stock (per young person), $\mathrm{K}$, is equal to the sum of the private captal stock, W*, and the capital held by the social security system. I. Recalling from (12) that the private capital stock is proportional to $w^{(0)}$, and recalling that the introduction of sociaj security reduces the value of $\mathrm{W}^{(0)}$, it follows that the introduction of social security reduces the private capital gtock. Moreover, it can be show that the reduction in the private capital stock, W*, is greater than $T$. Therefore, the national capital stock, $K_{*}=W *+T$, declines in response to the introduction of social security.

The effect of social security on the average level of consumption

6 Chu [7] extends this model to make the rate of return on capital and labor income endogenous. He further modifies the model to make social security caxes proportional to labor income and shows that linking the social security tax to income leads to different results about the distribution of wealth. 
can be calculated using the national income identity. To derive this identity, let $\mathbb{N}_{t}$ denote the number of young consumers born in period $t$. The assumption that each consumer has $G$ children implies that $\mathbb{N}_{t}-G N_{t-I}$. Gross national product in period $t$ is equal to the labor income of young consumers, $N_{t} Y$, plus gross capital income, $R N_{t-I}\left(W^{\star}+T\right), 7$ Gross national product is allocated to consumption and saving. Total consumption is equal to the consumption of the young consumers, $\mathrm{N}_{t} \mathrm{C}^{*}$, plus the consunption of the surviving old consumers, (1-p)N $t-x^{*}$. Gross national saving is equal to the saving of the young consuners. Not, plus the gross saving of the social security system, $N_{t} T$. Equating the sources and uses of gross national product yields

$$
N_{t} Y+R N_{t-1}\left(W^{*}+T\right)-N_{t} C^{*}+(I-T) N_{t-1} X^{*}+N_{t}\left(H^{*}+T\right)
$$

Equation (16) simply states that gross national product is equal to consumption plus gross investment. Dividing both sides of (16) by $\mathrm{N}_{t}$ and recalling that $N_{t} / N_{t-1}-G$ and $K *-W *+T$ yields

$C^{*}+[(1-p) / G] X^{*} Y^{*}+[\mathrm{R} / \mathrm{G}-1] \mathrm{K}^{*}$

The left hand side of (17) is aggregate consumption per capita.

7 The definitions of gross national product, gross capital income, gross national saving and gross investment used here differ somewhat fron those used in the national income accounts. Recall that one unit of capital in period $t$ yields $R$ units of the consumption good in period $t+1$... Using more standard terminology, $R$ is equal to $1-d+r$ where $d$ is the rate of depreciation and $r$ is the rate of return on capital before subtracting depreciation. With this notation, gross national product in period $t$ is $N_{t} Y+r_{t-1}\left(N^{*}+T\right)$; gross capital incone is $\mathrm{rN}_{t-1}$ (W*+T); gross investment, which is net investment plus depreciation, is $N_{t}(W *+T) \ldots$ $N_{t-1}\left(W^{*}+T\right)+d N_{t-1}\left(W^{*}+T\right)$; gross saving of the young generation is $N_{t} W^{*}$ : and gross saving of the old generation, which is net saving plus depreciation, is $-(1-p) N_{t-1} x^{*}+d(1-p) N_{t-1} W^{*}$. In the special case of complece depreciation, $d=1$ and therefore $R=r$. In this case, gross national product is $\mathrm{N}_{t} \mathrm{Y}+\mathrm{RN}_{\mathrm{t}-1}(\mathrm{~W} *+\mathrm{T})$; gross capital income is $R N_{t-1}\left(W^{*}+T\right)$; gross investment is $\mathrm{N}_{t}\left(W^{*}+\mathrm{T}\right)$; gross saving of the young generation is $\mathrm{N}_{\tau} \mathrm{W}^{*}$; and gross saving of the old generation is zero. Thus in the case of complete depreciation, the concepts of the gross national product, gross capital income, gross national saving and gross investment used in the text correspond to the standard national income accounting definitions. 
Recall that the introduction of fully funded social security leads to a reduction in the national capital stock, $\mathrm{K}^{*}$, on the right hand side of (17). If the rate of incerest exceds the population growth rate, then $R / G-I$ is positive and the reduction in $K^{*}$ implies a reduction in consumption per capita. Alternatively, if the interest rate is less than the population growth rate, then $R / G-1$ is regative and the reduction in the national capital stock $K *$ implies an increase in consumption per capita.

The relation between aggregate consumption and the aggregate capital stock in (17) is related to Pheips's $(23)$ famous Golden Rule result. In order to maintain a constant level of capital per capita, it is necessary that the capital stock grow at the same rate that population grows. Thus, if the level of capital per capita is to be increased perwanently by one unit, then the level of gross investment in each period must be increased by a units per capita. The benefit of increasing the capital stock by one unit per capita is that gross capital income is increased by $R$ units per capita. If $\mathrm{R}$ is greater than $G$, then the increased capital stock wil increase steady state consumption; whether the economy should temporarily decrease consumption in order to accumulate capital and increase long-run consumption depends on society's preferences for present consunption relative to future consumption. Alternatively, if $R$ is less than $G$, then steady state consumption can be increased by a decrease in the capital stock. There is no tradeoff between current and future consumption in this case. An increase in current consumption will reduce the capital stock and increase future consumption. Clearly, if an economy is ever in the case with $R<G$, it should decrease its capital stock; this would increase consumption at all 
dates, which would be Pareto-improving. 8

The case in which $R$ is equal to $G$ receives special attention. In a model with a neoclassical production function, the rate of return on capital, $R$, is a strictly decreasing function of the capital stock; hence, there is a unique value of the capital stock for which $R=G$. This value of the capital stock is called the Golden Rule capital stock. The Golden Rule capital stock is the capital stock that maximizes the permanently sustainable level of consumption. Any capital stock grater than the Golden Rule capital stock is too large in the sense described above, because $R$ would be less than $G$.

Pay-as-you-go Social Security: A pay-as-you-go social security system differs from a fully funded system in that the social security system does not hold any capital under a pay-as-you-go system; the taxes collected from the young consumers are used to pay the benefits to the old consumers in the same period. In each period, the young cohort is G/(1-p) times as large as the surviving old cohort... Therefore, setting total tax collections from young consumers equal to the total benefits paid to the old consumers yields the following relation between the social security parameters $S$ and $T$

$$
G T-(I-p) S
$$

The consumption of young type 0 consumers is calculated by substituting (18) into (6) to obtain

$$
c^{(0)}=a Y+a[1-(1-p) R / G](S / R)
$$

Equation (19) indicates that the consumption of young type 0 consumers may either increase or decrease with the introduction of payas-you-go social security, depending on whether $G$ exceeds or falls short 
of (1-p)R. This result is to be contrasted with the finding that fully funded social security unambiguously increases $c^{(0)}$. To understand this difference, one can view the social security tax $T$ as the price paid for a contingent clain that pays $s$ if the consumer lives for two periods. The gross rate of return on this claim is $s / T$. If this gross rate of return, $S / T$, exceeds the rate of return available on the consumer's portel10, $R$, then the introduction of social security will effectively make the consumer richer and wil increase consumption. However, if the rate of return on social securtey falls short of the rate of return on the consumer's portfolio, then the introduction of social security will reduce the consumption of young type 0 consumers. Now observe from (13) that the rate of return on fully funded social security, $S / T$, is equal to $R /(1-p)$ which exceeds $R$ if $p>0$. Thus, fully funded social security leads to an increase in $c^{(0)}$. Alternatively, (18) implies that the rate of retura on pay-as-you-go social security, $S / T$, is equal to $G /(1-p)$ which may be greater than, less than, or equal to R. Therefore, pay-as. you-go social security may lead to an increase, decrease, or no change in $c^{(0)}$.

Although the introduction of paymas-you-go social security may either raise or lower $c^{(0)}$, inspection of (7) reveals immediately that it unambiguouly reduces the saving of young type 0 consumers, $(0)$. As with fully funded social security, the reduction in $(0)$ implies that the inheritance recelved by each type $j$ consumer $(j>0)$ is reduced. Again, the reduction in all nonzero inheritances implies that the crosssectional variation in wealth is reducea. Also, the reduction in $w^{(0)}$ again implies that the per capita value of private wealth, $N *$, is reduced by the introduction of social security. Under pay-as-you-go social 
security, the government does not hold any capital; the national capital stock is equal to the private capital stock. Because pay-as-you-go social security reduces the private capital stock, W*, it also reduces the national capital stock. Again (17) indicates that consumption per capita will fall if the interest rate, $R$, exceeds the population growth rate, $G$, but will increase if $R$ is less than $G$.

\section{* - B. Annuities}

The model presented above has yielded some important insights about the behavior of individual and aggregate saving, and about the effects of social insurance, in the presence of uncertain individual longevity. However, the model has at least two unsetisfactory implications First, because consumers are assumed to be selfish, they would choose to hold ali of their wealth in annulties, even if the annulties were not actuarially fair. Provided that an annuity pays a greater return than riskless capital in the event the consumet survives, the consuner would choose to fully annutize his or her wealth. Thus, there is an incipient demand for annuities, and a satifactory treatment would either include annuties or would provide an economic reason why there are no annuities in equilibrium. The nodel presented above simply rules out annuties by assumption. However, annuities will be introduced into the analysis below.

The second unsatisfactory feature of the model is that the children of the richest consumers are among the poorest members of the economy if their rich, but selfish, parents live for two periods and thus leave no bequest. In this model, the only channel for the preservation of a family's wealth across generations is through accidental bequests which occur with early death. This feature of the model can be eliminated by 
introducing a bequest motive. In order to be abie to focus first on the implications of an anmity narket, the introduction of the bequest motive will be delayed until section $C$.

Now suppose that there is a competitive market for annuties. 9 Each dollar invested by a young consumer in an annuity yields Q dollars In the following period if the consumer survives; the consumer's estate receives nothing if the consumer dies after only one period of life. Insurance companies sell these annuties and invest the proceeds in raskless capital which pays a gross rate of return $R$. In the following period, insurance companies distribute the premiums with accrued interest to the surviving annutants in proportion to their contributions when young. The gross rate of return earned by survivors is equal to $\mathrm{R} /(\mathrm{l}-\mathrm{p}$ ). The introduction of a competitive annuty market into the model dramatically alters the nature of the equilibrium and the effects of social security. Because $R /(1-p)$ exceds $R$, annicies dominate riskiess capital and all consumers would choose to hold all of their wealth in the corm of annuties. Therefore there would be no bequests-accidental or ocherwise. Hence, there would be no cross-sectional variation in wealth. In this situation, it is appropriate to use a "representative consumer" nodel.

In the presence of an annuity inatket offering a gross rate of return $Q$, the consumption of a representative old consuner, $x$, is

$$
\mathrm{X}=\mathrm{Q} \mathrm{W}+\mathrm{S}=\mathrm{Q}[\mathrm{Y}-\mathrm{T}-\mathrm{C}\}+\mathrm{S}
$$

The optimai level of consumption when young can be calculated by

9 Kotlikoff and Spivak [20] discuss the role of the family in helping to provide annulties. The annulty protection offered by family members is not, of course, as complete as the insurance available in competitive annuity markets. Nevertheless, this annuity protection does affect consumer behavior. 
substituting the lifetime budget constraint (20) into the utility function (3) and then differentiating the resulting expression with respect to $\mathrm{c}$. Setting this derivative equal to zero yields

$$
c=a[Y-T+S / Q]
$$

where, as earlier, the marginal propensity to consume, $a$, is equal to $1 /[1+(1-p) D]$. Equation (21) states that the consumption of a young consumer is proportional to the present value of lifetine rescurces, where the future social security benefit, $S$, is discounted by the actuarial rate of return Q. Alternatively, recalling that in a competitive annulty market $Q=R /(1-p)$, the consumption function in $(21)$ can be written as

$$
c=a[Y-T+(1-p) S / R]
$$

The consumption function in (22) indicates that in the presence of a competitive annuity market, the appropriate concept of lifetime income is the expected present value of income.

\section{Fully Funded Social Security Now consider the effects of} introducing a fully funded social security system as characterized by (13) Substituting the social security parameters from (13) into the consumption function (22) yields

$$
c-\mathrm{I}
$$

Equation (23), which presents the optimal level of consumption of a young consumer in the presence of a fully funded social security system; displays a remarkable result. This equation indicates that the optimal level of $c$ is independent of the values of the social security parameters $T$ and $S$. Thus, the optimal level of $c$ is invariant to the introduction of fully funded social security.

The reason for the irrelevance of social security in the presence 
of a competitive annily market is that fully funded social security simply provides consumers with a redundant asset. As stated earlier, a consumer's claim to the social security benefit $S$ can be viewed as an asset with a gross rate of return equal to $S / T$. Under fully funded social security, this rate of return is equal to $\mathrm{R} /(1-\mathrm{p})$, which is precisely equal to the rate of return on privately available annuities. Thus, while the social securicy system essentially forces young consuners to purchase an anminy, the consumerg can exactly offset this effect by reducing their noldings of prive annities by an equal amount. Because the payoff characteristics of the private annuty are identical to those of social security, the consumer can obtain exactly the same statecontingent stream of consumption after the introduction of social security that could be obtained before its introduction. Furthermore, it till be optimal for the consuner to offset the effect of social security, because the initial state-contingent consumpion plan was optimal. Since the intzoduction of fuily funded social security does not change any relative price and does not change the consurer's opportunity set in any way, the original optimal plan remang optimal.

The irrelevance of fully funded social security in the presence of a competitive annity market is an example of a more general phenomenon that is known as the Ricardian Equivalence Theorem. Briefly, the Ricardan Equivalence Theorem states that changes in the timing of lumpsum taxes, holding constant the path of government spending, have no effect on the alocation of consumpion. The reason is essentially that consumers can, and will, offset the effects of such changes by adjusting their savings and/or bequest behavior.

As shown above, the Ricardian Equivalence Theorem applies to fully 
funded social security in the presence of an actuarially fair private annuity market. However, there are at least two sources of departure from the Ricardian Equivalence Theorem in the case of fully funded social security. First, it should be noted the invariance of consumption to the introduction of fully funded socical security is a direct consequence of the fact that the rate of return on social security is exactly the same as the rate of return on private annuities. If, for some reason, the rates of return on private annuites and social security were not identical, then the Ricardian Equivalence Theorem would not hold. For example, if the rate of return on social security exceeded the rate of return on private arnuties, then the introduction of social security would increase the expected present value of lifetine incone and would lead to an increase in the consumption of young consumers 10 of course, the question then arises as to why the government would be able to offer a higher rate of return on annuties than the private sector could. It would appear to be difficult the make the case that the government is more efficient in providing amuities, and it would also appear to be difficult to make the opposite case, a prior in alternative explanation, which is discussed below, is that if consumers face different mortality risks, and have private information about these risks, then the private annuity market would be subject to adverse selection. However, the goverment could; by requiring a compulsory level of social security coverage, be immune to adverse selection and thus offer a higher rate of return.

A second reason why the Ricardian Equivalence Theorem may not hold 
1s that if the social security tax is large enough, the consuner nay not be abie to offset it completely. Equivalenty, a large social security tax may fore the consuner to hold more of the publicly provided annuty than he or she fould have held of the prvate anuity. Therefore, the consuner would not be able to offset completely the effect of the pubilciy provided annuty by reducing private annuty holdings; the consumer yas simply not planing to hold that much wealth in private annuledes. Fomeliy, chis argunent can be stated by observing that the

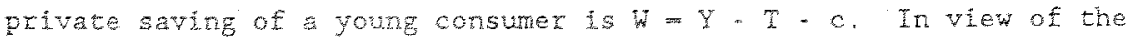
optral level of consumpton in (23), the optimal tevel of private saving of a young conswier is

$$
\text { H. }(1-a) Y-T
$$

Provided that $T$ is less than (1-a) the consuner could offset the efrects of social security by reducing the holding of private annuties

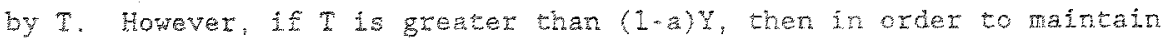
the originaly planed level of consumption, the consuner rould have to hold negecive amowt of andities. A negative holding of annuties could be achieved the consurer could botrow cesources and repay the debt if he or she survives but have the debt cancelled if he or she dies. The actuarially farr race of return on such loans would be $Q=\mathrm{g} /(1-\mathrm{P})$. The Reardian Equvalence Theorean would hold if the consunet could borrow at the actuaraliy fatr rate $Q$. However, if the consunet were unable to borrow tperhaps because the social security benefit is legally prohibited from serving as coliateraly, then the Ricardan Equivalance Theorem would Eall to nold if is greater than (1-a)y. In this case, social security would reduce the consumption of young consumers. 11 
Pay-as-you-go Social Security: Although a fully funded social security system is ineffectual in the presence of a competitive annuity market, this is not true, in general, for a pay-as-you-go system. To determine the optimal level of consumption under pay-as-you-go social security, substitute the social security parameters from (18) into the consumption function (22) to obtain

$\because c=a Y+a[G / R-1] T$

If the rate of interest exceeds the population growth rate, then $G / R$ - I is negative and the introduction of social security leads to a reduction in consumption of young consumers. The reason for this reduction is quite clear. The rate of return on pay-as-you-go social security, $S / T$, is equal to $G /(1-p)$ and the rate of return on private annuities is $R /(1-p)$.. Thus, if $R>G$, then the introduction of social security forces young consumers to hold annuities with a lower rate of return than is available in the private market. Therefore, consuners are made poorer by the introduction of social security and they reduce their consumption.

If the rate of interest is less than the population growth rate, then $G / R$ - I is positive and the introduction of social security increases consumption. Furthermore, the introduction of social security is Pareto-improving in this case. In the period in which pay-as-you-go social security is introduced, the members of the old generation are clearly better off because they receive the social security benefit $S$ without ever having had to pay social security taxes. In addition, each subsequent generation is made better off by the introduction of social security because it provides them with an annuity that dominates the effects of social security in the presence of borrowing constraints. 
annuity available in the private market. The Eact that the introduction of social security is Pareto-improving indicates that the initial equilibrium was not Pareto-eficient. Inded, the Golden Rule results discussed above indicate that if $R<G$, and if the capital stock is positive, then the economy suffers from an inefficient overaccumulation of capital. As applied to pay-as-you-go social security when $R<G$, the Colden Rule result indicates that any increase in $T$ and $S$ is paretoimproving until private saving by young consumers is driven to zero for, with a neociassical production function, until is equal to $G$ ).

\section{Bequest Motive}

The preceding analysis introduced annuties but has the shortconing that there are no bequests in the model. As a consequence, the distribution of wealth is degenerate. In order to generate bequests in $a$ model with a competitive amuity market, a bequest motive is introduced in this section. The two most comon formulatons of the bequest motive are altruisw and the joy-of-giving. Although these specifications are similar in wany xespects, they have different implications for the validity of the Ricardian Equivalence Theorem and the efficacy of fiscal policy.

Atruism: The altruistic specification of the bequest motive became popular in macroconomics after Barro's $[4]$ presentation of the Ricardian Equivalence Theorem. Under en astrustic specification of the bequest motive, a consuner obtains utility from the utility of his heirs as well as from his own consumption. Consider a consumer born in period twho consumes $c_{t}$ in period $t$ and, contingent on survival, consumes $x_{t+1}$ in period t+1. Let $v_{t}$ denote the cotal utility of this consumer and let $V_{t+1}$ denote the total utility of his or her representative heir, who is 
born in period $t+1$." Suppose that the consumer's utility function is

$$
v_{t}=\ln c_{t}+(1-p) D \ln x_{t+1}+\beta E_{t}\left(v_{t+1}\right)
$$

where $E_{t}$, denotes the expectation conditional on information in period 5. The parameter $\beta$, which is assumed to lie between zero and one, measures the strength of the altruistic bequest motive.

The utility of an altruistic consumer depends on his or her children's utility, which in turn depends on their children's utility, and so on. Thus, the utility of a consumer depends on the entire stream of consumption over his or her own lifetime and over the lifetimes of all of his or her descendents. Formally, the recursive specification of altruistic preferences in (26) is a linear difference equation that is satisfied by the following infinite-horizon utility function ${ }^{12}$

$$
v_{t}=\sum_{j=0}^{\infty}\left\{E^{j}\left[\ln c_{t+j}+(1-p) D \ln x_{t+1+j}\right\}\right.
$$

Now consider the effects of social security in the presence of an altruistic bequest motive. It is easiest to begin with the case in which all consumers live for two periods with certainty (Formally $p=0$ ). First, consider a fully funded social security system in which $R T=S$. As in the case without a bequest motive, fully funded social security Will have absolutely no effect. In response to the introduction of fully funded social security, young consumers will maintair their original Levels of consumption and will simply reduce their private saving by $T$. In the following period, when they are old, their portfolios of private assets will be worth RT less than in the absence of social security, but they will receive a social security benefit of S - RT that allows them to

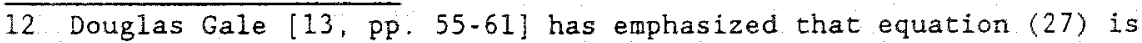
only one of an infinity of solutions to the difference equation in (26). However, (27) is the specification that is generally used in the literature. 
maintain the original level of old-age consumption.

Now consider the introduction of pay-as-you-go social security in which $S=G T$. Under altruistic preferences, it turns out that this policy also has no effect. The old consumers who are alive in the period in which social security is introduced will receive a payment of $S$ but they wil not increase their consumption at ail. Instead, they will choose to increase their bequest to each of their heirs by $S / G$. This increased theritance exactly offsets the tax burden $T$ levied on each of the young consurers. Thus, ali young and old consuners are able to maintain the origiral levels of consumption. Because ali relative prices and marginal rates of substicution renain unchanged, there is no incentive for anyone to change consumption.

The discussion above demonstrates that in the abserice of longevity risk and with atruistic preferences, the Ricardian Equivalence Theorem holds both fot fully funded social security and for pay-as-you-go soctal security. That is, private corsumption is invariant to the introduction of sochal secur ty whether it is fully runded of pay-as-you-go. When longevity risk is re-introduced into the model, the Ricardian Equivalence Theorem does not hold gute so generally. It does continue to hold for rully funded social security. Because the rate of return on fully funded social security, $S / T$, is equal to the rate of return on private annuties: $\mathrm{g} /(1-p)$; young consumers respond to the introduction of social security by reducing thein holding of private annities by $T$; they matrtain theif consuption unchanged.

The effects of pay-asmyoumo social security in the presence of longevicy risk and altruistic preferences are more interesting. Consider the period in which the pay-as-you-go social security system is 
introduced. All surviving old consumers receive a social security benefit $S=G T /(1-p)$. However, because a fraction 1-p of families have a surviving old consumer and the remaining fraction p of the families do not have a surviving old consumer; this payment to surviving old consumers induces a redistribution of wealth across families. In particular, there is a redistribution from families without a surviving old consumer to families with a surviving old consumer. Each surviving old consuner will see that the present value of his of her family's resources is increased by the introduction of social security: Therefore, surviving old consumers will increase their own consumption somewhat and will also increase their bequests somewhat in order to share the increase in wealth with subsequent generations. By contrast, the young consumers in families whot survivors will see a decrease in theit families' wealth and they will reduce their own consumption and their bequests

The argument above indicates that the Ricardian Equivalence Theorem fails to apply to pay-as-you-go social security under longevity risk, even if consumers have altruistic bequest motives However, a staunch defender of the Ricardian Equivalence Theorem would not concede the case so quickly. A defense of the Ricardian Equivalence Theorem would argue that the analysis in the paragraph above has ignored a relevant insurance market. More precisely, if the introduction of social security was at least conceivable in the prior period, then each young consumer would have taken steps to guard against the risk of having social security introduced during a period in which there were no surviving old consumers in his or her family. Each young consumer in the previous period would have agreed to give up any social security benefit, $S$, received in the 
subsequent period in exchange for $(1-p) s$ to be paid to the consumer, or his estate, in the following period. If this sort of tax liability Insuance arrangenent were fin force, then the introduction of pay-as-yougo soctal security fould have no effect on the allocation of private consmption. Although this argument is theoretically sound, it will urdosbcedy strike many readers as far-fetched. This type of insurance artangenert is not typically observed in practice, either because of legal prohibitions on trading future social security benefits or because of the Inited ability and or willingness of consuners to anticipate and whe contracts for ali conceivable contingencies.

Joy-of-giving: The altrustate specifiction of the bequest motive often fmples that individual consuners will take actions to completely nulligy the effects of various lump-sum tax and transfer policies. An alternative specification of the bequest motive is the joy of giving. Under the joy-of-ging conswets obtain utility from their ow consumption and from leaving a becuest. The utility from leaving the bequest deperds oniy on the size of the bequest; it does not depend on the utility or consurptoton of the recipients of the bequest. An example of a utilty function that displays a joy-of-giving bequest motive is $y_{t}=\operatorname{In} c_{t}+(1-p) D I n x_{t+1}+p H\left(B_{t}\right)+(1-p) H\left(B_{t}^{S}\right)$ where $\mathrm{B}^{b}$ is the bequest if the consuber dies after one period, and $\mathrm{B}^{\mathrm{S}} \mathrm{t}$ is the bequest if the consumer survives for two periods. Under the specification in (28), the utility from leaving a bequest of size $\mathrm{b}$ is H(b); it is assuned that $H^{\prime \prime}(\mathrm{b})>0$ and $\mathrm{H}^{\prime \prime}(\mathrm{b})<0$.

To analyze optimat consumption and portfolio behavior under the wtility function in (28), let $A_{t}$ denote the amount of weal th that the consumer holds in the form of anmities at the end of period t; the 
remainder of the portfolio, $I+Y-T-C_{t}-A_{t}$, is held in the form of riskless capital. If the consumer dies young, the bequest, $B^{D}$, is equal to the value of riskless capital with accrued interest

$$
B^{D}=\left[I+Y-T-c_{t}-A_{t}\right] R
$$

Alternatively, if the consumer survives for two periods, wealth in the second period consists of the principal and interest on annuities as well as on riskless capital; in addition, the consumer receives a social security benefit, $S$. Total available resources are allocated to consumption, $x_{t+1}$, and to the bequest, $B_{t}^{S}$, so that

$$
B_{t}^{S}-\left[I+Y-T-C_{t}-A_{t}\right] R+A_{t} Q+S-x_{t+1}
$$

The young consumer's consumption and portfolio decisions can be solved by substituting $(29 a, b)$ into (28) and then differentiating with respect to $c_{t}, x_{t+I}$ and $A_{t}$. The solution to this problem is presented in Abel [2], The discussion below focusses on a few interesting implications of optimal behavior.

Optimal behavior implies that the consumer would be indifferent between investing an additional dollar in riskless capital or in annuties 13 An additional dollar invested in annuities would be worth Q dollars in the following period if the consumer survives. This additional wealth could be used to increase the bequest $B^{S}$ by $Q$ units thereby increasing expected utility by $(1-\mathrm{p}) \mathrm{Q} \mathrm{H}^{\prime}\left(\mathrm{B}^{\mathrm{S}}{ }_{t}\right)$ Alternatively, an

13 If the consumer faces a binding constraint on the holding of riskless capital or annuities (such as a nonnegativity constraint), then he would not in gereral be indifferent about whether to invest an additional dollar in riskless bonds or in annuities. For this particular optimization problem, the consumer will choose to hold positive amounts of both riskless bonds and annuities provided that $\mathrm{H}^{\prime}$ (b) approaches infinity as $b$ approaches zero; thus, any nonnegativity constraints on the holdings of capital or annuities would not be binding. 
extra dollar invested in riskiess capital would be worth $R$ dollars in the following period regardless of whether the consumer dies or survives. In either case, the consumer could increase the bequest by $\mathrm{R}$ dollars: thereby increasing expected utility by $(1-p) R H^{\prime}\left(B^{S}\right)+p^{2} H^{\prime}\left(Q^{D}\right)$ dollars. Therafore, the consumer wil be indifferent betweer investing the dollar in tiskiess capital and antuties if

$$
-(1-\mathrm{p}) \mathrm{Q} \mathrm{H}^{\prime}\left(\mathrm{B}^{\mathrm{S}} \mathrm{t}^{\prime}=(\mathrm{I}-\mathrm{p}) \mathrm{R} \mathrm{H}^{\prime}\left(\mathrm{B}^{\mathrm{S}}\right)+\mathrm{pR} \mathrm{H}^{\prime}\left(\mathrm{B}^{\mathrm{D}} \mathrm{t}^{\prime}\right.\right.
$$

Recall that if the andutes are actuarialy fair, then $(1-p) Q=R$. In this case, it follows directy from $(30)$ that $\mathrm{B}^{\mathrm{S}} \mathrm{t}=\mathrm{B}_{\mathrm{t}}^{\mathrm{D}}$. That is, in the presence of acturianiy fair anuities, the consumer plans to leave the same beguest whether he or she lives for one or two periods. This resule deperds on the fact that the margingl utility of a bequest does not depend on whether the consurer Iives for one period or for two periods. In particular, the joy-of-giving function $H(b)$ does not depend on shether the consmer Itves for one period of two periods. (The same result also hotds under an altruistic bequest notive.) The intution behind this resut is that actuaraliy fat annuties permit the consumer to compietely insure the consumption basket which consists of $c_{t}, x_{t+1}$ : $\mathrm{B}_{\mathrm{b}}^{\mathrm{D}}$, and $\mathrm{s}_{\mathrm{C}}^{\mathrm{s}}$. The strategy to achieve Ful insurance is implemented by holing Jugt enough riskless capital to provide for the desired bequest and just enough annutios (including the contingent claim on the future social security benefit s) to provide for second-period consumption. 14 The introduction of a fully funded social secutity system has no effect under a joy-of-giving bequest motive. The reason, as in the absence of a bequest motive, and as in the presence of an altruistic 
bequest motive, is that the annuity provided by the social security system offers exactly the same payoffs as the privately available annuity. Therefore, consumers can, and will, choose to fully offset the effects of social security.

The effects of pay-as-you-go social security under the joy-ofgiving bequest motive differ quite dramatically from the effects under altruism. The difference is most clear in the case in which all consumers live for two periods with certainty $(p=0)$. Recall that under altruism, when the pay-as-you-go social security system is introduced, old consumers simply bequeath the payment, $S$, to their children in order to compensate them for their increased tax of $S / G$ per capita. However, under the joy-of-giving bequest motive, it would not be optimal for old consumers to maintain their consumption unchanged while increasing their bequests by $S$. The reason is that the utility from leaving a bequest depends only on the size of the bequest and not on the utility or consumption of the heirs. Thus, in response to receiving the payment $S$, old consumers would increase both their consumption and the bequest they leave. Essentially, consumption and bequests are both goods that enter the consumer's utility function, and, furthermore, these are the only arguments of the utility function. Consumption and bequests are each specified to be normal goods in (28) so that in response to an increase in income, the consumer optimally increases consumption of both of these goods :

The analysis in the paragraph above indicates that for the purpose of analyzing the Ricardian Equivalence Theorem, it is extremely important whether the bequest motive is of the altruistic or joy-of-giving variety. 
The reason is that under altrustic preferences the consuner cares about the entire stream of his or her family's consumption. Because the consumer does not care about the size of bequests per se, he or she is indifferent among changes in bequest patterns that maintain the initial allocation of consumption. Thus, in response to certain lump-sum tax and transfer poificies, the consumer mantains the original path of consurption simply by rearranging bequests. However, under the joy-ofGiving bequest notive, the consumer cares directly about the level of bequests, and therefore does not find it optinal to rearrange bequests while keeping consumption unchanged.

\section{D. heterogeneous Mortality Probabilities}

Up to this point it has been assumed that all consumers face identical mortality probabilities ex ante. However, if consumers have different probabilistes of survival, then there are additional chanels through which fiscal policy may operate. In addition, heterogeneity of ex ante mortality probabilities raises the possibility of adverse selection in the private annity market, which has important consequences for the prictig of annutias and for the efficacy of fiscal policy.

The implications of heterogeneous ex ante mortality probabilities are clearest in the absence of a bequest motive so the discussion below will be confined to this case. 15 In the absence of bequest motive, and in the presence of private andutives, all consumers will choose to hold their wealth entirely in amuities and hence there will be no bequests or inheritances. The major strategic decision in developing a model with

15 The effects of fiscal poifcy under heterogeneous mortality probabilites and a joy-of giving bequest motive are examined in $A b e 1$ [2] and $[3]$. 
heterogeneous mortality probabilities is whether to assume that an individual consumer's probability of dying, $p$ is known only by that consumer or whether it is a publicly available bit of information. The discussion below begins with the assumption that each consumer's value of $p$ is known by insurance companies. Next, the discussion will turn to the case in which the value of an individual's mortality probability is private information. These two cases are based on Abel $\{3\}$ and $\{2\}$, respectively.

Public Knowledge of Mortality Probabilities: Suppose that the ex ante mortality probability of each consumer is known to everyone, including insurance companies. Under this assumption, of course, competitive insurance companies will offer annuties with different rates of return to consumers with different values of $p$. Annuities will be priced to be actuarially fair to each consumer so that a consumer with a probability $p_{j}$ of dying young can buy annuities that offer a rate of return

$$
Q_{j}-R /\left(I-P_{j}\right)
$$

If follows immediately from (31) that consumers with a high probability of dying young will be able to purchase annuities with a high rate of return. Equivalently, these consuners can buy a given contingent payoff in the second period more cheaply than could healthier consumers who have a lower value of $p$. However, the expected rate of return on annuities, $\left(1-\mathrm{p}_{j}\right) \mathrm{Q}_{\mathrm{j}}$, is identical for all consumers and is equal to $\mathrm{R}$.

Suppose that all consumers have logarithmic preferences as specified in (3). Let $c(p)$ denote the consumption of a young consuner 
whose probability of dying young is equal to $p$. It follows immediately from the consumption function in (21) that

$$
c(p)=a(p)[Y-T+(I-p) S / R]
$$

where $a(p)=1 /[1+(1-p) D]$. Observe that the marginal propensity to consume, a $(p)$, is an increasing function of $p$. Thus, if $S-T=0$, then consumpton of young consumers would be an increasing function of $\mathrm{p}$. The reasor is that with logarithio preferences and no second-period income. consumption when young is independent of the rate of return on savings. Thus, the fact that consuners with a higher value of $p$ can obcain andities with a higer rate of return is irrelevant for the consumption deciston. However, because consuners 将th a high have a small chance of enforing consumption in the second period, they will consume more when they are young. This result, that c(p) is an increasing function of $p$, holds also for positive $S$ and $T$, provided that the values of these tax parangers arta sald.

Eully Funded Sociai Security: Now consider the effects of a fully funded socian security system that igrores differences in ex ante mortailty probsilintes. The assumption la not that the goverment is unabie to observe ex ante mottality probabilities that are observable by Insurance companies; rather, the assumption is that, for some reason, the sochal security system does not discriminate accotding to mortality probabilities. Under a fully funded social security systen, the benefits and taxes satisty

$$
\left(1-\mathrm{p}^{\mathrm{x}}\right) \mathrm{S}=\mathrm{RT}
$$


where $p^{*}$ is the average of the ex ante mortality probabilities of young consumers. Substituting the social security parameters from (33) into the consumption function (32) yields

$$
c(p)=a(p)\left[Y+\left(p^{*}-p\right) T /\left(1-p^{*}\right)\right]
$$

Observe from (34) that the consumption of young consumers with a higher than average probability of dying $\left(p>p^{*}\right)$ is reduced by the introduction of social security; the consunption of young conumers with a lower than average probability of dying is increased by the introduction of social security. These effects on consumption reflect the fact that non-discrininatory social security redistributes income from consumers wh thigh value of $p$ to consumers with a low value of $p$. The social security system forces consumers to hold an annuty with gross rate of return $S / T-R /\left(1-p^{*}\right)$. For consuners with $p>p^{*}$, this rate of return is less than the rate of return avaliable on private annuties and thus these consumers are made pooret by the introduction of social security, By contrast, for consumers with $p<p^{*}$, the annutey providet by social securicy offers a higher rate of return that is otherwise available to them Hence these consumets are made wealthier and increase their consumption.

The introduction of social security shifts resources and hence consumption, away from consumers with a high value of p toward consumers with a low value of $p$. Because consumers with a high value of $p$ initially had high consurption relative to consumers with a low value of $p$, this redistribution of resources reduces the cross-sectional variation in consumption. Note that the mechanisu for reducing cross-sectional variation differs from the mechanism in the case without annuties and 
with accidental bequests. In that case, the gource of cross-sectional variation was accidental bequests; by zeducing savings, social security ceduced accidental bequests and cross-sectional variation. In the presere model, there are no bequests. The source of variation, in the absence of social security, is the difference in marginal propensicies co consure which results from different mortality probabilities.

- In addition to reducing cross-sectional variation in consumption, the fritroduction of fully funded social security reduces the average leval of consumption of young consurers. This reduction in average consumption arises because the social security system transfers zosources Fron consumers wh a high marginat propensity to consume high consumets) to consumers with a low marginal propensity to consume (10w consuners). This result can be derived formaly by defining $E(Z(p))$ as the population average value of some arbitrary function $z(p) .16$ with

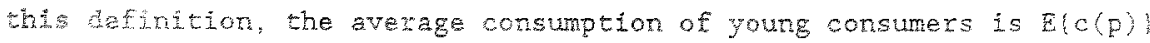
Where

$$
\left.E(c(p))=E(a(p))+E+E\left(p^{*}-p\right) a(p)\right) T /\left(1-p^{*}\right)
$$

It can be shown formally that $E((p *-p) a(p))$ is negative. Intutively, the reason is that $\left.2\left(p^{*}-p\right) a(p)\right\}$ is equal to $E\left(p^{*}-p\right) E(a(p))$ t. $\operatorname{Cov}\left(\mathrm{p}^{*}-\mathrm{p}, \mathrm{a}(\mathrm{p})\right)$. Because $\mathrm{E}\left\{\mathrm{p}^{*}-\mathrm{p}\right\}$ is, by definition, equal to zero, it

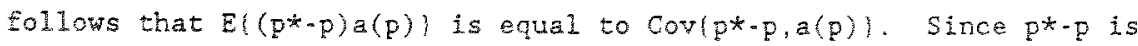

16 At a formal level, let $f(p)$ denote the density function of the ex ante mortality probability $p$. With this definition, the average ex ante probability $p^{*}$ is equal to 1
1
average value of $Z(p)$. 
decreasing in $p$ and $a(p)$ is increasing in $p$, this covariance is negative. Therefore,

$$
E\left(\left(p^{*}-p\right) a(p)\right)<0
$$

The inequality in (36). implies that the coefficient of $T$ in (35) is negative. Therefore, as argued above, an increase in $T$ leads to a reduction in average consumption of young consumers.

- Private Information and Adverse Selection: Now suppose that there is heterogeneity of ex ante mortality probabilities, and that individual mortality probabilities are private information. More specifically, suppose that each individual consumer knows his or her own ex ante mortality probability, but that no one else knows that person's value of p. However, the distribution of ex ante mortality probabilities in the population is public knowledge. This information structure gives rise to a classic adverse selection problem. In the case of annuties, the high risk consumers from the viewoint of insurance companies are those consumers with a low mortality probability $p$. These consumers will demand more annuties than the consumers with high mortality probabilities and they will be more likely to survive and receive anmity payments.

In general, the equilibrtum in the presence of adverse selection is either a pooling equilibrium, in which consumers do not reveal their private information, or a separating equilibriun in which the optimal behavior of consumers reveals their private infomation. To simplify the determination of the market equilibrium, an additional assumption will be made. In particular, assume that an insurance company cannot determine whether any given consumer has purchased annuities from other insurance 
companies. The force of this assumpion is to rule out separating equilibria in which consumers with different mortality risks face different rates of return on annuties. If insurance companies tried to charge higher prices (i.e., offer lower rates of return) to consuners with low $p$, then these consumers would masquerade as high $p$ consumers and Yould buy only a small amount of annuties at a given insurance company. Then these consumers would satisfy their relatively large demand for annuties by purchasing additional annuties from one or more other companies. Therefore, an insurance company's attampt to separate its customers by offering offerent quantities of annities at different prices would fail. Instead, the market would be characterized by one wate of return that is offered on all annuties. Because of adverse selection, this rate of return would have to be lower than $R /\left(1-p^{*}\right)$, Which is the actuarially fair rate based on population average mortality. In the absence of a bequest motive the demand for annities by a consiner will be equal to the consumer's savings, which is equal to first-period income, $Y$. T, minus consumption in the first period. Let A(p;Q) denote the amount of annuity demanded by a young consumer with a mortality probability $p$ when the rate of return on annuties is $Q$. Using the consumption function in (21), it follows that

$$
A(P ; Q)=[1-a(P)][Y-T]-a(p) S / Q
$$

Equation (37) implies that in the absence of social security (S $=T$ - 0 ), the demand for annuities is invariant to the rate of return they offer. This invariance is a consequence of the offsetting income and substitution effects associated with logarithmic utility. Now recall that $a^{\prime}(p)>0$ which implies that $1-a(p)$ is a decreasing function of $p$. 
Thus, if $Y-T-S / Q>0$, then the demand for annuties is a decreasing Eunction of $\mathrm{p}$.

The equilibrium rate of return on annuties is such that the expected profit of insurance companies is equal to zero. Insurance companies will, on average, earn posithve profits on annuties sold to consuners with high values of p but will, on average, suffer losses on annuties sold to consuners with low values of p. More precisely in the absence of social security, the expected profit on annuties sold to a consumer with mortality probability $\mathrm{p}$ is $[\mathrm{R}$ - (1-p)Q]A(p;Q). Let $\pi$ denote the expected profit of the amnity industry averaging over all consumers, and observe that

$$
\pi=E(R-(1-p) Q) A(p ; Q))
$$

This expression can be rewritten using the fact that $1-p=(1-p *)+$ $\left(p^{*}-p\right)$ to obtain

$$
\pi \quad\left[R-\left(1-p^{*}\right) Q\right] E\left(A(p ; Q)-E\left(p^{*}-p\right) A(p ; Q)\right) Q
$$

Observe that $E\left(p^{*}-p\right)=0$ and recall that in the absence of sociat security, $A(p ; Q)=[1-a(p)$ Iy Thus, in the absence of social security, the expected profit of the anruity industry can be rewritten as

$$
\pi / L=[R-(1-p+) Q[E[1-a(p)]+E(p *-p) a(p)) 10
$$

The two terms on the right hand side of (40) have a simple interprecation. The first term is the expected profit of the annuity industry that would prevali if all consumers purchased the same amount of annuties regardless of their ex ante nortalities probabilities. The second term, which is negative according to equatior (36), represents the expected losses inflicted on insurance companies due to adverse selection. Observe that each of the two terms on the right hand side of 
(40) is a decreasing function of $Q$. Therefore, the expected profit of the annity industry is strictily decreasing in the zate of return offered on annities. In addition, note that if the race of return on annuities ig actuarially far based on the population average probability p*, 1 , if $\mathrm{Q}=\mathrm{g} /\left(\mathrm{I}-\mathrm{p}^{\mathrm{W}}\right)$, then the sirst term on the right hand side of (40) would be equal to zero. In this case, $\pi / X$ would equal $E\left(p^{*}-p\right)$ a $\left.(p)\right\}$ which is negative. Therefore, any rate of recurn on annuitus greater than or equal to $R /(1-p+)$ would iead to expected losses for the annity frdustry and could not an equilibrium.

The equilibrium rate of return of anulties must yield zero spected proftes on anduties. In this case, with logarithmic utility. and in the absence of social security, this rate of return is unique. Setting the expected profit, $\pi$, equal to zero in (38) yields

$$
Q=E(E-a(p)) / E(Q-p)(1-a(p))\}
$$

Fuly Funded Social Security: Now consider the effects of introductig fully funded social security. Although social security has the payoff characteristics of an annity, there is an important afference between social sacurity ard the annities available in the private market. Because the social security system forces all young consumers to "purchase" equal amounts of the annuity it provides, the social security system is imme to adverse selection. The rate of return implicit in social security, $S / T$, is equal to $R /\left(1-p^{*}\right)$ as in (33).

To calculate the effect of social security on the national capital stock, substitute the relation between the social security parameters 5 and $T$ in (33) into the annuity demand function (37) to obtain $A(p ; Q)=[1-a(p)] Y-T-\left[R-\left(1-p^{*}\right) Q\right]\left[a(p) /\left(1-p^{*}\right) Q\right] T$ 
Recall that as a consequence of adverse selection, $R+\left(1-\mathrm{p}^{*}\right) \mathrm{Q}>0$. Therefore, equation (42) indicates that the introduction of fully funded. social security reduces the derand for annities by more than $T$; hence, the private capital stock falls by moze than $T$. The demand for annuities would decrease by precisely $t$ if $Q$ were equal to $R /\left(I-p^{*}\right)$. However, because social security provides an annulty wht a larger payoff than is availeble on private annuties, the introduction of social security. expands the opportunity set of all consumers and hence induces all consuners to increase their consumpton when young. This increase in consumption means that the private capital stock falls by more than $T$. Therefore the national capital stock, wich is equal to the private capital stock plus $T$, also declines. ${ }^{17}$

In order to determine effects of social security on the equilibrium rate of return on private anuities, first calculate the change in the structure of the demand for private anmities. Differentating the annuity demand function in (42) with tespect to $T$, and evaluateng the derivative at $S=\mathrm{I}=0$, yields

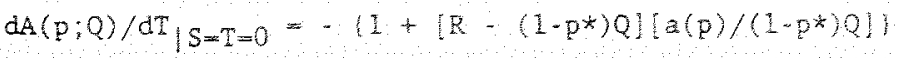

The term in curly brackets on the right hand side of (43) is an increasing function of p... Therefore, consuners with a tigh value of $p$ reduce their demand for annules by a greatez anount than consumers with a low value of $p$. Since consumers with a high value of p began with a Lower anuity demand than low $p$ consumers, it is clear that the high $p$ consumers reduce their demand for annuties by a larger fraction than do 17 This reduction in the private capital stock depends on the absence of a bequest notive. If there is a sufficiently strong joy-of-giving bequest motive, then the national capital stock may increase in response to the introduction of fully funded social security... See Abel [2]. 
the low $p$ consuners. Hence the shere of annities bought by high $p$ consumers is reduced, which reduces the expected profits of the annity industry. In order to restore zero expected profits. It is necessary for the rate of return on annutides to decine.

In coneluding the discussion of anvity merkets, it is useful to

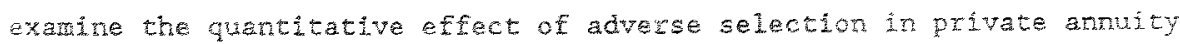

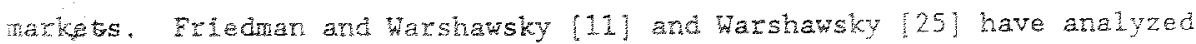
andity prices and the mortality experiences of anduty purchasers th the unted States. They found that annuty purchasers tend to dive longer

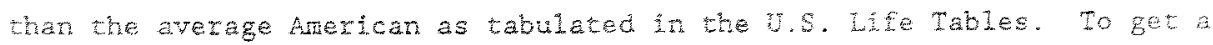
measure of how much longer amulty purchasers live, they calcunate load factors. The gross load factor is defined as the rato of the price paid for an annity to the expected present value of the payments accring to an emuity purchaser: the net load factor is equal to the gross load tactor minus one. These 1 oed factors are calculated under two different assuptons abut mortality: In one calculation, the mortality probablities ate taken from the U. S. Wre Tabjes and in the other calcuation, the mortalicy probabijities are calibrated to match the wetrality experience of annuty purchasers. Not surprisingly, they fond that the expected present value of payments using anuity purchasers artality is greater than the expected present value of payments using the y.S. Life Table. Therefore, the load factor based on annuty puchasers' mortality is less than the load factor based on the U.S. Life Table. Very coughly, the average net load factor based on the U.S. Life Tabie was around 30 cents on the dollar; the average net load factor based on the mortalicy of annity purchasers was about 15 cents on the 
dollar. The difference in load factors, 15 cents on the dollat was attributed to adverse selection. 18 However, the extert to which the difference in mortality probabilities was private information or public information could not be determined from these studies.

Although the load factors reported in these studies are substantial, they do not appear to be large enough to explain the widespread shunning of annity markets by private consumers. Friedman and Warshawky (11) attribute at least part of the reluctance of consumers to buy annuties to a bequest motive, but unanswezed questions remain. For example, to what extent do consumers hold bequeathable wealth rather than level-payment amuties as a precaution against the need to make very large medical expendtures? Perhaps this risk of catastrophic medical expenditure explains the fact that retired consumers decumulate theit wealth much more slowly than predicted by the life-cycle model. Clearly more research into these risks and consumers reactions to these risks is needed.

Sumary: The discussion of the effects of fiscal policy in the presence of longevity risk has examined several different sets of assumptions about bequest notives, the type of fiscal policy and the availability and pricing of annulfies. Father than sumarize a11 of these cases, a few of the major themes will be highlighted. The insight of the Ricardian Equivalence Theorem is that fiscal policy will affect

18 More precisely, Friedman and Warshawky [11] exanine data for the period 1968-1983 and find load factors of $32-48$ cents on the dollar using the U.S. Life Tables; they find load factors of $18-33$ cents on the dollar after allowing for adverse selection. Harshawsky (25) examines data from the period $1919-1984$ and finds load factors of 10.29 cents on the dollar using the U.S. Life Tables. He attributes 8 to 16 cents on the dollar of these load factors to adverse selection. 
private economic activity ony if it changes the opportunities availabie to andividuals. Such changes in opportunities could take the form of changes in relative prices or changes in the present value of resources.

In appitying the insight of the Ricerdan Equivalence Theoren to social securty, it is useful to think of social security as an annuty because consurers pay something then they are young in exchange for sonething that they will recerve only if they survive. Clearly, if there Is wo naket in which consumer can buy anmuties, then the introduction of social security changes consumers opportunity sets by providing an annity. Not only does the introduction of social security affect the saving dectsions of consurers who rocetve no bheritances, it also reduces the inheritances of those people tho do recelve them. Alternatively, if there is a private market for amuities, then the introduction of social security will have an effect only if the annity provided by social security offers dfferent terms than those offered by pravatuy traded annuties. If consumers have identical mortality Fobabilities and if the rate of return on privare annuties is actuarially fair, then fully funded actal security offers the same rate of return as private annutiss and thus has no efect. This invariance of economic behavior to the introduction of fully funded social security holds regardless of whether consumers have a bequest motive or not and holds regardless of the form of the bequest motive.

There are several reasons why the rate of retum on social security may differ from the rate of return on private annities. First, pay-asyou-go social security offers an expected rate of return equal to the population growth rate rather than the rate of return on capital. Thus, 
in general, pay-as-you-go social security offers a different rate of return from the rate of return in competitive annity markets. Second, if consumers have different mortality probabilities and if individual consumers possess private information about their own mortality probabilities, then the private annuity narket will be subject to adverse selection which drives down the rate of return on annuities. In this case, fully funded social security would offer a higher rate of return than private annuties. Third, even if each individual consumer's mortality probability is publicly knom, then social security will haye an effect if the governent decides not to discriminate on the basis of mortality probabilities... In this case, the government offers the same taxes and benefits to all consumers, but in the private market consuners face different prices for a given level of second-period benefits. Therefore, for at least some consuners, socid security will offer a different rate of return than private anduties.

It might seen that if the rate of return on social securty is different from the rate of return on privately available annuites, then the introduction of social security would have an effect on private saving decisions. This presumption is indeed true if consumers do not have bequest motives of if they have joy-of-giving bequest motives. However, if consumers have altruistic bequest motives, then it may be that social security has no effect even though it offers a rate of return that differs from the rate on any privately traded asset. For instance, in the absence of longevity risk, fully-funded social security would have no effect even though the rate of return on social security differs from the rate of return on capital. However, in the presence of longevity 
risk, the Ricardian Equivalence Theorew could fail to hold even under a] torisism.

\section{Incone $\mathrm{R}$ isk}

In the previous sections of this paper, the risks have best confined to uncertainty about the length of an individual's iffetime. The market for life insurance and annities allows consumers to reduce the stacts of these risks snd, as discussed above, the functioning of these markets has important implications for the efiects of fiscal policy. This section wil ignore longevity risk and focus instead on the ras associated with an individual's future labor incone. Future labor incone strisky for two reasons. First, there is a chance that a consuner will not be able to work as a result of an accident ox inlness. Second, ever if the consumer is able to work, future income will Phetuate as a result of fluctuations in productivity or in the demand tar his or her setrices. Because disability insurance is available to reduce, or even eniminate, the first of these sources of incone risk, the dfscussion 11 ignore this source of risk, focussing instead on the secont source of income risk.

At first glance, it appears that there is no insurance available to zeduce the risk associated with fluctutations in productivity or in demand. Although there is no active insurance market to reduce the whingss of a future income stream, the income tax system provides a Form of income insurance. If the income tax rate is constant, say at 27\%, then the goverment essentially shares $27 \%$ of the risks associated wh fluctuations in labor income. Not only does the income tax provide 
risk reduction as would more conventional types of insurance, it is also subject to the problem of moral hazarc, as discussions of the laffer Curve have made clear More precisely, while the income tax provides some insurance against fluctuations in labor income, it also provides a disincentive to work: the Laffer Curve is based on the possibility that a tax rate increase will reduce work effort to such an extent that income tax revenue would decline. In order to isolate the risk-reducing effects of the income tax, and to focus or precutionary saving, the analysis will be based on the assumption that labor supply is perfectly inelastic. Therefore, future labox incone will be treated as an exogenous stochastic variable from the vierpotnt of the individual consumer.

Consider a consumer who lives fox two periods and receives exogenous income $y_{1}$ and $y_{2}$ in periods 1 and 2 , respectively, The consumer pays total taxes $t_{1}$ and $t_{2}$ in periods 1 and 2 , respectively. The deterimation of the consumer's cax bill will be discussed in nore detail below. Let $c_{1}$ and $c_{2}$ be consumpton in periods 1 and 2 , respectively The saving of a young consuner is $y_{1}-t_{1}-c_{1}$ For simplicity, suppose that the net rate of return on saving is equal to zero. In this case the consumer's second-period consumption is equat to saving plus second-period Iroone net of taxes, $y_{2}-t_{2}$

$$
c_{2}-y_{1}-t_{1}-c_{1}+y_{2}-t_{2}
$$

Suppose that the consumer's utility function is

$$
u\left(c_{1}\right)+u\left(c_{2}\right)
$$

Now consider a young consumer's saving decision. When making this decision, the consumer knows the values of $y_{1}$ and $\tau_{1}$ but knows only the probability distributions of $y_{2}$ and $t_{2}$. At the optimal level of 
consumption, the consumer is indifferent between consumg an additional unit in period 1 and increasing savings by one unit. If $c_{1}$ is increased by one unit, then the congurer's utility increases by $u^{\prime}\left(c_{1}\right)$.

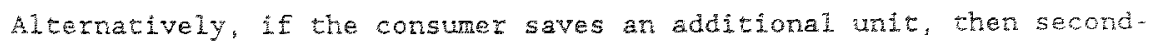
perad consumpton, $c_{2}$, fnoreases by one wint, which increases expected

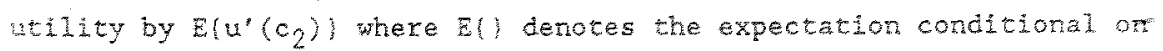
Erst-period information. The optimal consupton deciston is cheracterized by

$$
x^{*}\left(c_{1}\right) \Rightarrow \mathrm{z}^{*}\left(\mathrm{u}^{*}\left(\mathrm{c}_{2}\right)\right.
$$

\section{A. Certainty Equivaience}

Suppose, for the moment, that the wedity function w(c) is Guadrate: $u(c)=-c_{2} / 2+b c$, where the parameter b ts positive. In this case, the marghal utitility is linear in consumpton

$$
y^{\prime}(c)--c+b
$$

Substituting the margind utidity function (47) anto the firstster conditan (46) yidids

$$
\varepsilon_{2}\left(c_{2}\right)=c_{1}
$$

Equation (48), which displays Robert Hall's [15] fanous random walk theory of consumption, indicates that the expectation of future consumption is equal to current consumption. Equivalenty consumption follows a random wik. The reason is that, with concave utility, consumers attempt to mitigate fluctuations in consumptor over time. In response to an increase in income, a consuner fncreases both current consumption and planned future consumption. In the case with quadratic utility and equal rates of interest and time preference both are zero in this particular case), it turns out the increases in $c_{1}$ and the expected 
value of $c_{2}$ are exactly equal. Under a more general utility function. consumption does not follow a randon walk exactly, but the marginal utility of consumption does follow a random walk as in (46).

The optimal level of $c_{1}$ under quadratic utilicy can be determined by substituting the budget constraint (44) into the first-order condition (48) to obtain

$$
=c_{1}-(1 / 2)\left[y_{1}-t_{1}+E\left(y_{2}-t_{2}\right)\right\}
$$

The consumption function in (49) displays the permanent income/life cycle theory of consumption. It states that consumption is a function of the expected present value of lifetime income, net of taxes. In this particular example, it is optimal to consume one half of expected Iifetime income in the first period. The consumption function in (49) also illustrates the certainty equivalence principle More generally, the certainty equivalence principle applies to optinization problems with a quadratic objective function and linear constants with additive uncertainty, It states that optimal decision rules depend on the expected values of random variables, but do not depend on any other moments of the distributions of the random variables. In particular, the variance of the random variables is irrelevant and may as well be assumed to be zero. Equivalently, the optimal decision rule is identical to the rule that would prevail if all random variables were equal to their expected values with certainty.

Precautionary saving is defined as the additional saving induced by the introduction of uncertainty about future income. Because the consumption function in (49) is independent of the variance of future income, it is not useful for examining precautionary saving. Although 
the quadratic wility function on which (49) is based displays risk aversion, optimal behavior does not display precautionery saving. An increase in the variance of $y_{2}^{-t}$ reduces the expected utility of the consumer; however, it does not change the consuner's behavior at aII. if there were actuarally farr insurance aganst the risks associated whth second-period incone, the consumer mould buy it. However, the consume would choose the same level of or regardess of whether or not such Insurance Is avaliable. In terms of the specification of the Whity function, risk aversion recuires positive second derivative, but precautionary saving cegures a positive thitd derivative. 19 The guadratic utility functon, of course, has a positive second dexivative but a zero third derivative.

\section{B. Precautionary Saving}

Now consider a utility function with a positive thro derivative so

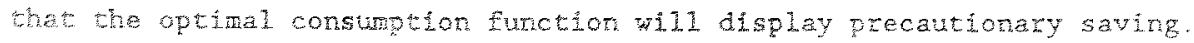
For smpictur, suppose that the utility function is $u(c)=-e x p[-k c]$ where $k>0$ is the coefficient of absolute risk aversion. 20 The marginal atility function is

$$
\mathrm{u}^{\prime}(\mathrm{c})=\mathrm{k} \operatorname{\mathrm {K}} \mathrm{x}[-\mathrm{kc}]
$$

Substituting the utility function from (50) into the first-order condition (46), and using the budget constaint (44) to eliminate $c_{2}$, yeids

$$
\exp \left[-\mathrm{kc}_{1}\right]=\mathrm{E}\left(\exp \left(-k\left(\mathrm{y}_{1}-\mathrm{t}_{1}+\mathrm{y}_{2}-\mathrm{t}_{2}-c_{1}\right)\right]\right.
$$

19 For an excellent discussion of the relation between risk aversion and precautionary saving, see rimball [18].

20 KimbalI and Mankiw [19] examine the precautionary saving of an infinite-horizon consumer wh a constant absolute risk aversion utility function. They use their model to examine the interaction of tax policy and precautionary saving in a richer dynamic framework. 
To calculate the expectation on the right hand side of (51); the distribution of the random variable $y_{2}-t_{2}$ must be specified. Suppose that $y_{2}-t_{2}$ is normally distributed with mean $E\left(y_{2}-t_{2}\right)$ and variance $\operatorname{var}\left(y_{2}-t_{2}\right\}$. Under this distributional assumption, the expectation of $\exp \left[-k\left(y_{2}-t_{2}\right)\right]$ is equal to $\exp \left[-k E\left(y_{2}-t_{2}\right)+(1 / 2) k 2 v a r\left(y_{2}-t_{2}\right)\right]$ and equation (51) can be rearranged to yield

$$
=-c_{1}=\left[y_{1}-t_{1}+E_{1}\left(y_{2}-t_{2}\right)-(1 / 2) k \operatorname{var}\left(y_{2}-t_{2}\right)\right] / 2
$$

The consumption function in (52) displays precautionary saving. Consumption in the first period is a linear and decreasing function of the variance of second-period after-tax income. Therefore, saving is a linear and increasing function of the variance of future after-tax income.

\section{Fiscal Policy}

The simple consunption function in (52), which displays precautionary saving, can be used to examine the interaction of precautionary saving and various tax policies In particular, this Eramework can be easily used to examine the impact of both lump-sur cares and income taxes. Many of the results presented below were derived for a more general utility function by Louis Chan 161 In this particular model, as in Chan's model, income is exogenous so that the incentive effects of taxes on labor effort will be ignored. By treating income as exogenous, this model focusses on the insurance aspects of the income tax.

Suppose that the second-period tax consists of a head tax, t*, plus a proportional income tax, at rate $\tau(0 \leq \tau<1)$, so that

$$
\tau_{2}-t^{\star}+\tau y_{2}
$$


and after-tax income is given by

$$
y_{2}-t_{2}-(1-\tau) y_{2}-t *
$$

Now consider an increase in the income tax race 7 accompanied by a zedution in the head tax th that leaves the expected second period tax paymenc, $\mathrm{E}\left(\mathrm{s}_{2}\right)$, unchanged. Because the expected tax payment is held Fixed, this change in tax structure leaves E\{y $\left.y_{2}-t_{2}\right\}$ whchanged. Howner, the increase in ineduces the vartance of after-tax income,

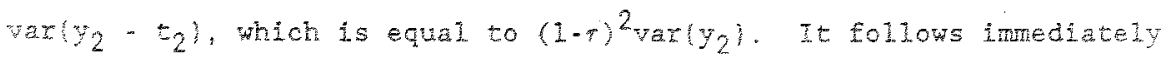
strom (52) that this reduction in the variance of aftex-tax income induces an frecease in first-period consumpton. Thus, when the income insurance

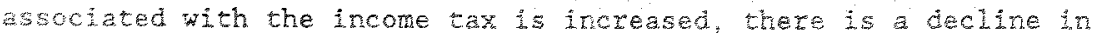
precatponary saving. Note, in additon, that this fncrease in the Income tax rate, compensated by a decrease in the head tax, leads to an morease in expected utility.

The next step in the analysis of fiscal policy is to examine agregate income and to specify the relation between inditidual incone thid aggregate incone. Let $w_{2}$ denote the level of aggregate income per capted in the second-period. Suppose that individual income, $y_{2}$, is

$$
y_{2}=Y_{2}+e
$$

Where e represents the idiosyncratic random comonent of incone and Ele $=\mathrm{E}\left(\mathrm{Y}_{2}\right)=0$. These assumptions imply that the idiosyncratic component. \& A uncorrelated with aggregate incore $\Psi_{2}$.

In examining various tax and trangfer policies, one must make sure that the policy changes satisfy the govemment's budget constraint. For simplicity, suppose that all consumers pay the same tax, ti, in period 1 and that all consumers pay the same head tax, t*, in period 2 . Second 
period tax bills will differ across consumers to the extent that their second-period incomes differ. The government budget constraint states that total tax revenues over the two periods must equal total government spending over the two periods. Latting g denote the total value of government spending, the government's budget constraint is

$$
t_{1}+t^{*}+\tau Y_{2}=g
$$

- The lifetime tax liability of an indivicual may be calculated by adding $t e$ to both sides of (56), and using the fact that $Y_{2}=Y_{2}+e$, to obtain

$$
t_{1}+t^{*}+\tau y_{2}=g+\tau e
$$

Observe that the left hand side of (57) is equal to $t_{1}+t_{2}$. Therefore, equation (57), along with (55), can be used to rewrite the first-order condition (51) as

$$
\begin{aligned}
& \exp \left[-k c_{1}\right]= \\
& \quad E\left\{\exp \left[-k\left(y_{1}+y_{2}-g+(1-\tau) e\left(-c_{1}\right)\right]\right)\right.
\end{aligned}
$$

To calculate the expectation on the right hand side of (58), the distributions of the random variables $Y_{2}$ and e must be specified. It has already been assumed that $e$ has a mean equal to zero and that $Y_{2}$ and $e$ are uncorrelated. In addition, assume that $\mathrm{Y}_{2}$ and e are each normally distributed. Under this assumption, the expectation on the right hand side of (58) can be calculated Simplifying this expression yields

$$
\begin{aligned}
& c_{1}-(1 / 2)\left(y_{1}+E\left(Y_{2}\right)-g\right) \\
&(1 / 4) k\left[\operatorname{Var}\left(Y_{2}\right\}+\operatorname{Var}((1-\tau) e)\right]
\end{aligned}
$$

The consumption function in (59) embodies both the optimization of the individual consuner as well as the government's budget constraint. It can be used to examine the effects of various fiscal policies. Note 
that the governent's budget constrant involves four policy variables: the first period tax $t_{1}$, the second-period head tax t*, the second-period income tax fate $t$, and the total value of goverment expenditure, $g$. However, ony two of these four variables, namely $g$ and $\tau$, enter the consumption function in (59). Thus, consumpton in the first-period toes not atrectly depend on the first-period tax, $z_{1}$, nor on the second-period beat tax t*. This observation immedately suggests a policy change for which the Ricardian Equivalence Theorem applies. Consder a one dollar increase in the first-period tax, t $t_{1}$, accompanied by a dectesse in the second-period head tax t*. This change satisfeg the government budget constrant. It is ciear from (59), that since neither of these tax parameters entexs the consumption function, this cemporary tak increase has no effect on consumption.

Next, consider a tax charge for which the Ricardian Equivalence Theoptrif does not apply. In particular, consider an increase in the first period tax to thet 1 s accompanied by an approprate decrease in the scond-period income tax rate $\uparrow$, as determined by the government budget constraint. In examining the effects of this tax policy, it is useful to focus on two special cases of the randon processes for incone. First, consider the case in which there is no uncertainty about future aggregate income $\mathrm{h}_{2}$. In this case, which corresponds to the case considered by Barsky, Mankiz and Zeldes [5], the consumption function in (59) can be written as

$$
c_{1}-\left\{y_{1}+g\left(Y_{2}\right\} \cdot g \cdot(1 / 2) k(1-\tau)^{2} \operatorname{var}(E)\right\} / 2
$$

It follows inmediately from (60) that the increase in $t_{1}$ and the accompanying decrease in $\tau$ will reduce first-period consurption, provided 
that Varle $>0$. The reason for this reduction in consumption is that the reduction in the future tax rate $t$ implies that the goverment will be sharing a smaller fraction of the idiosyncratic income risk. As a consequence, the consumer wil face a greater income risk and thus fill increase precautionary saving.

Alternatively, consider the case in which aggregate income $\mathrm{Y}_{2}$ is uncertain but there is no idiosyncratic risk (i.e. varlel $=0$ ): In this case, the consumption function in (59) can be written as

$$
c_{1}=\left[y_{1}+E\left(Y_{2}\right)-g-(1 / 2) k V a r\left(Y_{2}\right)\right] / 2
$$

In the absence of idiosyncratic income risk, none of the three tax parameters enters the consumption function in (6I). Therefore, an increase in $t_{1}$ accompanied by an approprate decrease in $T$ has no effect on consumption. Thus, the Ricardian Equivalence Theorem applies in this case. The reason is that, even though there is uncertainty about future aggregate income and about the tax rate on future income, there is no uncertainty about the future tax liability of any consumer. Each consumer pays an extra dollar in taxes in period 1 . Therefore, the aggregate tax revenue in period 2 must be reduced by one dollar per capita. Because the idiosyncratic component of income has been assumed to be identically zero, each consumer knows with certainty that his or her second-period tax bill will be equal to the aggregate per capita tax bill. Since the aggregate per capita tax bill will fall by one dollar, each consumer knows with certainty that his or her future taxes will fall by one dollar, exactly offsetting the one dollar increase in period 1 taxes. Therefore, there is no change in the optimal level of first period consumption. 
The effect of changes in the tax rate $T$ have dramatically different effects depending on whether the uncertainty associated with second period income is idiosyneratic or is common to all consumers. If the second period income risk is idiosyncratic, then an income tax allows consuners to share risk with each other. Therefore, a reduction in the income tax rate would reduce the extent of insurance and would lead to incressed precautionary ging. By contrast, If there is no idosymerate component to second pertod frome risk, then individual. consuners cannot reduce their rasks by shang with other consuners. In this case, the income tax foes not provide any insurance and the Reardian Equivance Theorem holds. Although aggregate risks camot be shared across memers of a generation, it is possible that aggregate risks cowld be shared across generation. Intergenemational risk sharing is exanined in the next section.

\section{Intergeneratonai Rik Sharing}

Virtualiy all of the risks discussed in previous sections are Hath-generational risks in the sense that differente members of the sane gemeration obtan different realizations of a randon yariabie. Except cor problens of adverse selection and moral hazard, hese risks could be potentialy shared among members of the same cohort. By contrast, this section wil focus on risks that camot be shared among members of the ang cohort because al1 members of a fiven cohort face the same risk ex post as well as ex ante. To be more specific, this section will examine incone shocks that strike all members of a cohort to exactly the same 
degree. If there is to be any risk sharing, it must be done by sharing risks among two or more generations.

Intergenerational risk-sharing has been studied by Roger Gordon and Hal Varian $[14]$; the discussion below draws heavily on their analysis and extends their model to allow for population growth. Consider an economy with overlapping generations of consumers, each of whom lives for two periods. Each generation is $G$ times as large as the generation that preceded it. A consumer who is born in period $t$ receives a perfectly storable deterministic endoment w in pexiod t and receives a random endowment e $t+1$ in period t+1. Suppose that $e_{t+1}$ has a mean of zero and is identically and independenty distributed across generations For simplicity, consumption is confined to the second period of life. Let $c_{t+1}$ denote the consumption in period t+1 of a consumer born in period $t$ The realized value of the consumer's utility in period $t+1$ is $u\left(c_{t+1}\right)$, where the utility function $u(\lambda$ is serictly increasing and strictly concave.

All members of generation t face the same value of the random variable $e_{t+1}$. Therefore, there is no scope for within-generation risksharing. Also, because adjacent generations are simultaneously alive for only one period, there is no scope for private markets to share risks across members of adjacent generations. Therefore, if there is to be intergererational risk sharing, then a long-lived institution, such as a government, must be involved.

Consider the following scheme to share risks. Suppose that the government levies a tax of $\tau e_{t+1}$ (where $0 \leq \tau \leq 1$ ) on each old consumer in period $t+1$, and uses the proceeds of the tax to give a subsidy of 
$e_{t+1 / G} / 0$ each young consuner in period $t+1$. Of course, if $e_{t+1}$ is negative, then old consurers receive an unlucky realization of income and the tax levied on old consuners is negative. Thus, if $e_{t+1}$ is negative, the cax system transters resources from the young consumers to the old consumers. In the presence of this tax systen, the consumption of an old consumer in period $t+1$ is

$$
=c_{t+1}=w+(\tau / G) e_{t}+(1-\tau) e_{t+1}
$$

The, this tax scheme spreads the risk associated with the randon endownent across two adjacent generations.

\section{A. Optimal Risk Sharing}

Now consider the value of the tax rate 7 that maximizes the ex ante utility of a generation t consumer, E$\left(u\left(c_{t+1}\right)\right)$, where the expectation is calculated at the beginning of the consumer's life, prior to observing the realization of the random variable $c_{t}$. This is the tax rate that a constrer would choose if he had no knowledge of the particular Teanzations of random incone that would occur during his lifetime. The watuation of the optimal value of is simplified by using $(62)$ to

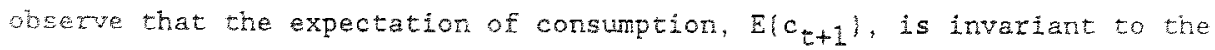
tax rate? (because $\Sigma\left(c_{t+1}\right)$ w). Thus, because the utility function u() Is concave, the optimal tax rate is the rate that minimizes the unconitional variance of consumption. Tt follows inmediately from (62) that the unconditional variance of consumption is

$$
\left.\operatorname{var}\left(c_{t+1}\right)=(\tau / G)^{2}+(1-\tau)^{2}\right) \text { Varle }
$$

The optimal value of $r$ can be found by differentiating (63) with respect to $\tau$ and setting the derivative equal to zero to obtain 21 


$$
\left.\tau=1 / 1+G^{-2}\right]
$$

Observe from (64) that in the absence of population growth, i.e. with $G=1$, the optimal value of $t$ is equal to $1 / 2$, In this case. optimal risk spreading across pairs of adjacent generations involves each generation having a 50 stake in each of the two drawings of e that take place while that generation is alive: More generally, with $G>1$, the optimal value of $r$ is greater than $1 / 2$. Substituting the optimal value of $r$ from (64) into the expression for consumption (62) yields

$$
c_{t+1}=w+\left[G /\left(1+G^{2}\right)\right] e_{t}+\left[1 /\left(1+G^{2}\right)\right] e_{t+1}
$$

If $G$ is greater thar one, then the coefficients on e $e_{c}$ and $e_{c+1}$ are each less than $1 / 2$. Thus, in the presence of population growth, it is possible for generation to have less than a 50 stake in the risk associated with $e_{c}$ and $e_{t+1}$.... Each old consumer lays off more than half of the old-age income risk on the younger generation. However, because the younger generation has more people than the older generation, it can absorb this increased risk with an increase in risk per person that is smaller than the reduction in risk per old consumer.

\section{B. Time Consistency}

The optimal intergenerational fiscal insurance system presented above was derived under the assumption that this system will remain in force. However it may turn out that some cohorts may not want to participate in the fiscal risk-sharing arrangement. When a generation is old and receives a positive value of $e_{t+1}$, this generation would like to sever its participation. This type of desire to pull out of a system will not be considered here. If these old consumers had, when they were 
young, yoluntarily decided to participate in the risk-sharing arrangement, then they w12 not be allowed to renege on their implied contract just because they received a positive value of ettl.

The interesting question conceming the piability of the fiscal insurance system is whether young consumers in period t wi1, after iearning the value of $e_{t}$, choose to partacipate in this system. The reason they may choose not to participate is that if et is negative, they axe required to nake a net transfer to old consumers. If the value of the risk reduction provided by the fisea insurance system is less than the value of the required transfer, then these young consumexs bil choose not to participate. However, if the value of the risik reduction exceeds the value of the required transfer, then young consumers would choose to participate in the fiscal insurance systeri. 22

Gordon and Varian $\mid 14$ argue that yourg consumers in period $t$ win refuse to participate in the fiscal insurance system whenever $e_{t}<0$. mest model assumes a constant population size so, for the moment. suppose that $G$. To keep the argument simple, suppose that $e_{t}$ is a

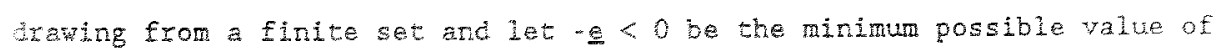
a. First, suppose that es of. In this case, each young consurer is reguired to pay $\mathrm{e} / 2$ in tazes. If in the following period, $e_{t+1}=-$ en then each generation t consuner would receive a fiscai subsidy of $e / 2$ and

22 This analysis assumes that if a generation decides not to participate in the Fiscal insurance system when it is young, then it is precluded from receiving payments from a fiscal insurance system when it is old, otherwise, if young consumers believed that the choice of whether or not to participate in the fiscal system when young would have no effect on whether they would receive payments when they were old, then young consumers would never choose to pay the fiscal insurance tax. 
thus would have consumption equal to w - e, which is the same that consumption would have beer without participating in the fiscal systen.

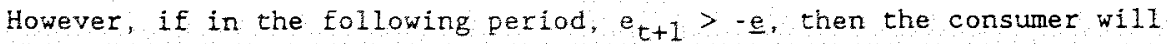
either receive a fiscal subsidy less than $e / 2$ or will pay a tax. Thus, the consumer will end up having paid more into the system than he or she got out of it. Therefore, the best that the young consumer can hope for is to-break even by participating in the system, and, in general, the consumer will be worse off ex post. Clearly, such a consumer will choose not to participate in the system in this case.

The argument above establishes that if $e_{t}=-e_{\text {, then the generation }}$ t consumers will not participate in the fiscal insurance system. Now suppose that there is some value $e^{*} \geq$-e such that the generation $t$ consumer will choose to participate in the system if and only if $e e^{*}$. It is now straightforward to demonstrate, by contradiction, that ex cannot be negative. Suppose that $e_{t} e^{\star}<0$. In this situation a young generation $t$ consumer is required to pay $\left|e^{*}\right| / 2$, But how much will the consumer receive in the following period? If $e_{t+1}<\varepsilon^{*}$, then the generation $t+1$ consumers will not join the system, and hence the generation $t$ consumer will receive nothing from the fiscal insurance system. If $e_{t+1}>e^{*}$, then the generation $t$ consumer will either receive a subsidy smaller than $\left|e^{*}\right| / 2$ or will pay a tax.. In either of these situations, the consumer is worse off for having participated in the fiscal insurance system. Only if $e_{t+1} e^{*}$ will the generation $t$ consumer end up as well off under the fiscal insurance system as without it. Thus, as above, the consumer cannot possibly be made better off by 
joining the fiscal insurance systen and will, in general, be made worse off. Therefore, he or she wi11 not join. Thus, ex camot be negative. Gordon and Varian discuss mechanisms that would avoid the repeal of the intergenerational fiscal insurance system. For example, if large enough coste are imposed on any young cohort thet tries to repea the Esscin insurance system, then no generation and equilibrium the costs will not have to be borne. For example, if the abandonert of the fiscal. Ansurance system leads to economic or socian upheaval, then the young generation may decide that che costs exceed any pecuniary gains from avojding participation in the fiscal Lisurance syster.

In addition to the mechanisms discussed by cordon and Varian for sustaning a fiscal insurance system, there is the possibility that popuation growth can sustan the system. If all generations have the ame number of consumers, then the stze of the maximum transfer paid by a Pong consumer ${ }^{2}$ s equal to the size of the maximum transfer that this consuer could possibly receive when ofd. Therefore, as argued above, when a young consumer is required to make the maximum possible transfer, the consumer cannot possibly expect to benefit from participating in the Siscal insurance system. However, if each generation is $G$ times as large as the preceding generation, then the largest transfer that can be received by an old consumer is $G$ times as large as the largest transfer that a young consumet could be reguired to make. Thus, even if a young consumer had to pay the largest possible transfer, it is still possible that the consumer could receive an even larger transfer in the following period. Depending on the consumer's attitude toward risk, it may turn 
out that even faced with the largest required payment when young, the consumer wauld choose to participate in the fiscal insurance system.

To demonstrate that population growth may be able to sustain voluntary participation in the fiscal insurance system, it may be clearer to use a numerical example than an algebraic proof. Suppose that each generation is twice as large as the generation preceding it, i.e., $G=2$. In this case, it follows from (64) that an optimal fiscal insurance system will set $t$ equal to $4 / 5$. Substituting $G=2$ and $t=4 / 5$ into the equation for consumption (62) yields

$$
c_{t+1}-w+0.4 e_{t}+0.2 e_{t+1}
$$

The value of consumption in $(66)$ is based on the assumption that the fiscal insurance system remains intact. As an example, suppose that w - 11 and that there are only three possible values for e - 10 , 0 , and 10. Assume that $e=-10$ and $e-10$ are equally probable and let $q<1 / 2$ denote this common probability... Therefore, the probability that e - 0 is 1-2q. Thus, since consumption, $c_{t+1}$ depends on $e_{t}$ and $e_{t+1}$, there are nine possible value of $c_{t+1}$ which are displayed in Table 1 . Each row corresponds to a value of et and each colum corresponds to a value of $e_{t+1}$

Consider a young consumet in period $t$ and suppose that $e_{\tau}=-10$, so that this young consumer is faced with paying the largest possible transfer. To determine whether this consumet will choose to participate in the Eiscal system, the values of consumption in the first row of Table I must be compared with the values of $c_{t+1}$ if the consumer does not participate ir the systen,. These values are shown in Table 2. 
Comparing the values of consumption in the first row of Table 1 with the values of consumption in Table 2, it is clear that neither row dominates the other in a stochastic dominance sense. By participating in the fiscal insurance system, the consumer retuces the variance of consumption Erom $200 \mathrm{q}$ to $8 \mathrm{q}$ at the cost of reducing the expected value of consumption from 11 to 7 . Whether consumet vews the reduction in $\mathrm{x}$ isk as. woth the proce depends on his or her atritude toward risk and on the value of $\mathrm{g}$. Clearly the more aversion the consumer has to risk, the more atroctive is the ziscal insurance gysem.

Suppose that the utility function $1 \mathrm{a} u(c)=-1000 \mathrm{exp}[-\mathrm{ko}$ ) where $k$ Is the coeficient of absolute risk aversion. Assume that $\mathrm{a}=0.25$. If $k$ - 1 , then the expected utility if the consurer participates in the fiscal insurance systen is -2.27 ; the expected utility if the consume does not participate in the system is $=91.97$. Thus, the system will be sustaned by voluntary patticipation is this case.

In the example above, all generations voluntarily choose to patiopate in the fiscal insurance. Because all generations obtain Bigher utility with the introduction the fiscal insurance system, such a system is Pareto-improving. In this particulax example, the net rate of return on savings is zero, so that using the notation from section II, I. 1. Therefore, in this example, $R<G$ so that Golden Rule considerations indicate that a Pareto-improvement could be achieved by increasing consumption and reducing saving. The determination of the optinal fiscal system, which might include both an element of intergenerational risk sharing and an elenent of lump-sum 
intergenerational transfers to stimulate consumption, remains an open question for research.

\section{Concluding Remarks}

This paper has analyzed the effects of various fiscal policies in situations in which individual consumers face various sorts of risks. Methodologically, the research presented in this paper is quite neoclassical. Although the models employed in this paper are very much in the spirit of those erabraced by the so-called new classical school of macroconomics, the results differ quite dramaticaliy from some of the most well-known new classical results. In particular, the Ricardian Equivalence Theorem, which essentially states that lump-sum tax policies have no effect, is an important result that pervades much of the new classical literature. The results zeported in this paper often deviate importanty from the Ricardian Equivalence Theorem. The departures from the Ricardian Equivalence Theorem, and hence the effects of fiscal policy, depend importantly on the availability and the nature of insurance arrangements to protect individual consumers against vartous types of risk. It is perhaps ironic that the tradicional Keynesian model, which emphasizes the effects of fiscal policy has no place for insurance arrangements to interact with fiscal policy. It is in the neoclassical Eramework, which is based on the optiming behavior of consumers facing risk, that the interaction of insurance and fiscal policy becomes apparent. Further research into the nature and evolution of insurance arrangements will help to extend understanding of the effects of fiscal policy. 


\section{Table 1}

values of $c_{t+1}$ under the fiscal insurance system

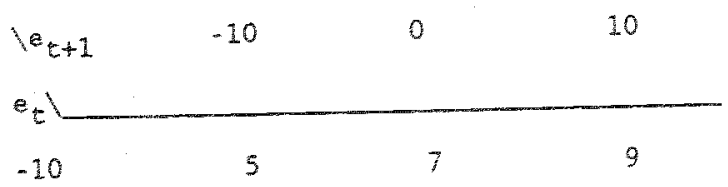

\begin{tabular}{llll}
\hline 0 & 9 & 11 & 13 \\
\hline 10 & 13 & 15 & 17 \\
\hline
\end{tabular}

Table 2

Values of $c_{t+1}$ in absence of fiscal insurance

$e_{t+1}: \quad-10 \quad 0 \quad 20$

$c_{\tau+1}: \quad 1121$




\section{References}

1. Abel, Andrew B., "Precautionary Saving and Accidental Bequests," American Economic Review, 75, 4 (September 1985), 777-791:

2. Abel, Andrew B., "Capital Accumulation and Uncertain Lifetimes with Adverse Selection," Econometrica, 54, 5 (September 1986), 1079. 1097.

3. Abel, Andrew B. "Aggregate Savings in the presence of Private and Social Insurance," in Rudiger Dornbusch, Stanley Fischer and John Bossons (eds.) Macroeconomics and Finance: Essays in Honor of Franco Modigliani (Cambridge, Mass... M.I.T...Press) 1987, 131-157.

4. Barro, Robert 1 , "Are Government Bonds Wet Wealth," Journal of Political Economy, 82 (November/December 1974), 1095-1117.

5. Barsky, Robert B., N. Gregory Mankiw and Stephen P. Zeldes, "Ricardian Consumers with Keynesian Propenities;" American Economid Review, 76, 4 (September 1986), 676-691.

6. Chan, Louis K. C., "Uncertainty and the Neutrality of Government Financing Policy," Journal of Monetary Economics, 11 (May 1983), 351-372.

7. Chu, Cyrus, "The Effect of Social Security on the Steady State Distribution of Consumption," The Institute of Economics, Academa Sinica, Nankang, Taipei, Taitun Discussion Paper No, 8601 , September 1986 .

8. Davies, James B., "Uncertain Lifetime, Consumption, and Dissaving in Retirement, " Journal of Policical Economy, 89, 3. (June 1981), 561: 577.

9. Diamond, Peter A. "National Debt in a Neoclassical Growth Model, American Economic Review, 55 (December 1965), 1126-1150.

10. Eckstein, Zvi, Martin S. Eichenbaum and Dan Peled, "The Distribution of Wealth and Welfare in the Presence of Incomplete Annuity

Markets," Quarterly Journal of Economics, 100, 3 (August 1985), 789806.

11. Frledman, Benjamin $M$, and Mark Warshawsky, "The Cost of Annuities: Implications for Savings Behavior and Bequests," mimeo, Harverd University, September 1984.

12. Friedman, Milton, A Theory of the Consumption Function (Princeton N.J.: Princeton University Press), 1957. 
13. Gale, Douglas, Money: in disequilibrum, Cambridge University Eress, Cambridge, 1983.

14. Gordon, Roger and HaI R. Varian, "Intexgenerational Risk Sharing," mimeo, Univeristy of Michigan, February 1985.

15. Hall, Robert E., "Stochastic Iuplications of the life CyclePermanent Income Hypothesis: Theory ard Evidences:" Iournal of Folitical Economy, 86 (Decenber 1978), 971.987.

16. Hubbard, R. Glenm and kenneth I. Jud, "Social Security and Individual Helfare, "American Econoulc Review: 77,4 (September $-1987), 630-646$.

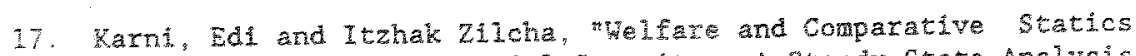
Mmplications of Fair Social Seevirty: A Steady State Analysis," Iournal of public Econonics, 30,3 (August 1987 ), $341-357$.

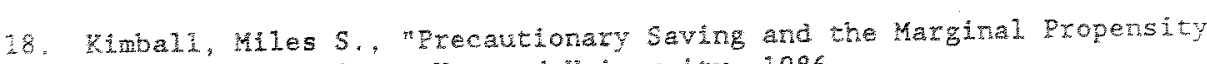

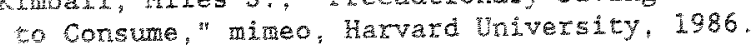

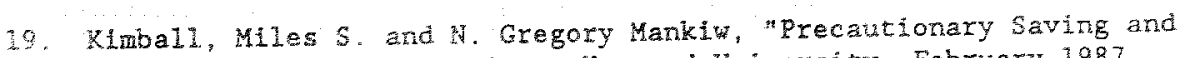
the Thing of Tayes, " mimeo, Harvard University, February 1987.

20. Lotlikoff, Laurence J. and Avia Splvak, "The Family as an Incomplete Annuitses Marker, Journal of Po Pitical Economy, 89 (Apri1 1981). $372-391$.

2. Fompof, Laurence I, and Lawrence Sumpers, "The Role of

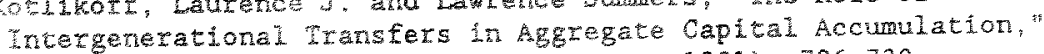
Journa of political Econony, 90 (August 1981 ), $706-732$.

22. Modiglani, Franco and Richard Brumberg, "Utility Analysis and the Consumption Function: An Interpletation of Cross-Section Data," in kaneth K. Kurhara (ed.) Post Kemesian Economics, Rutgers University Press; 1954.

23. Phelps, Edmund S., "The Golden Ruie of Accumulation: A Fable for Growthmen," American Econonic Review, 51 (September 1961), 638-643.

24. Sheshinski. Eytan and Yoram Weiss, wUncertainty and Optimal Social Security Policy," quarterly Journal of Economics 96,2 (May 1981). $189-206$.

25. Warshawsy, Mark, Annuity Prices in the United States, mimeo, Board of Governors of the Federal Reserve System, September 1986.

26. Yari, Menachem, "Uncertain Lifetime, Life Insurance, and the Theory of the Consumer," Review of Economic Studies, 32 (April 1965), 137 150. 